\title{
Wielki Sobór Kościoła Prawosławnego na Krecie w 2016 r. i jego ustalenia
}

\author{
ks. Andrzej Kuźma \\ Chrześcijańska Akademia Teologiczna w Warszawie \\ Polska \\ akuzma65@wp.pl
}

rev. A. Kuźma, The Great and Holy Council in Crete in 2016 and its Arrangements, Elpis, 20 2018: 165-179.

\begin{abstract}
This article discusses the Council of the Orthodox Church, which took place in Crete in 2016. Due to its content, the text has been divided into two parts. In the first part, the preparatory process is briefly presented. The procedure of creating the documents and their approval as projects for the future Council by the Pre-Conciliar Pan-Orthodox Council is also presented. In the second part, the content of the documents, which were accepted at the Council, are analyzed. In order to present their content more systematically, the documents have been divided into three categories: A) general documents, B) documents concerning the inner life of the Church, C) documents concerning the external life of the Church.
\end{abstract}

\begin{abstract}
Streszczenie: Artykuł omawia Sobór Kościoła prawosławnego, który odbył się na Krecie w 2016 r. Pod względem treści tekst został podzielony jest na dwie części. W pierwszej części w sposób skrótowy został ukazany proces przygotowawczy do Soboru. Została ukazana procedura powstawania dokumentów i ich akceptacji jako projektów na przyszły Sobór przez Ogólnoprawosławne Konferencje Przedsoborowe. W drugiej części została przeprowadzona analiza treści dokumentów, które zostały przyjęte na tym Soborze. Dla bardziej systematycznego przedstawienia ich treści, dokumenty zostały podzielone na trzy kategorie: A) dokumenty o charakterze ogólnym, B) dokumenty odnoszące się do wewnętrznego życia Kościoła, C) dokumenty odnoszące się do zewnętrznego życia Kościoła.
\end{abstract}

Keywords: Great and Holy Council of the Orthodox Church, Pan-Orthodox Council, Crete 2016, Council documents

Słowa kluczowe: Wielki Sobór Kościoła Prawosławnego, Sobór Ogólnoprawosławny, Kreta 2016, dokumenty Soboru

W dniach 18-26 czerwca 2016 r. na greckiej wyspie Kreta, po wielu latach przygotowań odbył się Wielki i Święty Sobór Kościoła Prawosławnego. Pomimo wielu wysiłków całego współczesnego Prawosławia włożonych w jego przygotowanie, Sobór nie był sukcesem jakiego oczekiwano. Przyczyną takiego stanu rzeczy była odmowa wzięcia udziału w obradach przez kilka Kościołów autokefalicznych. Niemniej jednak rezultatem obrad Soboru jest sześć dokumentów tematycznych, poprzedzonych Przestaniem Soboru i Orędziem Soboru, które zostały przyjęte przez Ojców soborowych. Spośród sześciu oficjalnych dokumentów, dwa wyrażają stosunek Prawosławia i Kościoła prawosławnego do współczesnego świata i są to dokumenty: 1) Relacje Kościoła prawosławnego z pozostalym światem chrześcijańskim, i 2) Misja Kościoła prawosławnego we wspótczesnym świecie. Wkład Kościoła prawostawnego w osiagnięcie pokoju, sprawiedliwości, wolności, braterstwa i miłości między narodami oraz zniesienie dyskryminacji rasowej i innej. Natomiast cztery spośród tych dokumentów odnoszą się do zagadnień, które dotyczą wewnętrznego życia Kościoła prawosławnego: 1) Ważność postu i jego wypetnienie dzisiaj, 2) Autonomia i sposób jej ogtaszania, 3) Prawostawna diaspora i 4) Sakrament matżenstwa i jego przeszkody ${ }^{1}$. Ponadto, należy zauważyć, że

Dokumenty zostały opublikowane w czterech językach oficjalnych: dwa dokumenty wstępne tj. Orędzie Soboru i Przestanie Soboru ${ }^{2}$ stanowią również głęboką i ważną refleksję teologiczną współczesnego Prawosławia.

\section{Część I Kontekst historyczny}

\section{Przygotowania do Soboru}

Zamysł zwołania i przeprowadzenia Soboru, który zgromadziłby wszystkie lokalne autokefaliczne Kościoły prawosławne jest ideą sięgającą początków XX w. Jednak o rzeczywistych inicjatywach zwołania Wszechprawosławnego Soboru możemy mówić poczynając od roku 1923. Na Wszechprawosławnej konferencji, która miała miejsce w czerwcu 1923 r. w Konstantynopolu zaproponowano aby w roku 1925 odbył się Wszechorawosławny

greckim, rosyjskim, angielskim i francuskim. Pozostają one dostępne w wersji elektroniczne na stronie www.holycouncil.com. Tłumaczenie wszystkich dokumentów w j. polskim [w]: Cerkiewny Wiestnik 4/2016.

2 Pełny tytuł wspomnianych dokumentów: Orędzie Świętego i Wielkiego Soboru Kościoła Prawosławnego i Przesłanie Świętego i Wielkiego Soboru Kościoła Prawosławnego do prawosławnego ludu i wszystkich ludzi dobrej woli. Tekst oryginalny i tłum. pol. ibidem. 
Sobór, który w ten sposób uczciłby 1600- lecie zwołania I Soboru Powszechnego. Na ten Sobór mieliby przybyć nie tylko biskupi lokalnych Kościołów prawosławnych, ale też przedstawiciele tych Kościołów, które przyjmują Niceo- Konstantynopolitański Symbol Wiary. Pomimo wielu wysiłków i zaangażowania wpływowych osobistości nie doszło do zwołania Soboru w 1925 r. Idea zwołania Soboru była jednak kontynuowana ${ }^{3}$.

Intensyfikacja przygotowań miała miejsce na początku lat 50-tych. Działania te były efektem aktywnej postawy i działań patriarchy ekumenicznego Atenagorasa I (18861872). Rzeczowe i osobiste zaangażowanie się patriarchy $\mathrm{w}$ proces przygotowawczy poskutkowało tym, że $\mathrm{w}$ dniach 24 września -1 października 1961 r. na Rodos odbyła się I Konferencja Ogólnoprawosławna. Uczestniczyli w niej przedstawiciele wszystkich lokalnych Kościołów (oprócz Kościołów: Albanii, Gruzji i Finlandii). Najważniejszym rezultatem spotkania na Rodos w kontekście przygotowań soborowych okazał się katalog tematów dla przyszłego zgromadzenia. Ponadto konferencja na Rodos okazała się manifestacją jedności całego Prawosławia, które w wyniku rewolucji październikowej w Rosji w 1917 r. i nowego podziału politycznego zaistniałego po II Wojnie Światowej znacząco zmieniło swoje oblicze. Na Konferencji postanowiono, że każdy autokefaliczny Kościół lokalny wypowie się odnośnie ustalonych zagadnień na przyszły Sobór. Taka metodologia okazała się bardzo trudna i jednocześnie przekraczała możliwości wielu Kościołów ${ }^{4}$. Należy zaznaczyć, że w kolejnych latach na Rodos odbyły się jeszcze dwie Konferencje Ogólnoprawosławne 26-29 września 1963 i 1-15 listopada 1964 dotyczyły one jednak przede wszystkim uczestnictwa prawosławnych w Soborze Watykańskim i dialogu z Kościołem rzymskokatolickim.

Kolejna IV Konferencja Ogólnoprawosławna odbyła się w dniach 8-15 czerwca 1968 r. w nowo otwartym Centrum Patriarchatu Ekumenicznego w Chambésy k. Genewy. Konferencja okazała się ważnym etapem w procesie przygotowawczym. Powołano m. in. stały Sekretariat do Spraw Przygotowania Świętego i Wielkiego Soboru. Na stanowisko sekretarza został powołany metropolita Szwajcarii Damaskinos (Papandreu). Przyjęto postanowienie aby periodycznie zwoływać Międzyprawosławne Komisje Przygotowawcze, które będą zajmowały się przygotowywaniem dokumentów na przyszły Sobór. W skład Komisji wchodziły dwuosobowe delegacje z każdego autokefalicznego Kościoła. W ten sposób wypracowane przez Komisję

\footnotetext{
Wiele inicjatyw i działań zostało podjętych w celu zwołania Soboru w okresie poprzedzającym wybuch II Wojny Światowej. Dokładny opis historyczny zob. T. Kałużny, Nowy Sobór Ogólnoprawosławny, Kraków 2008, s. 139-152. Krótszy opis A. Kuźma, Historia i aktualny stan przygotowań do zwołania Soboru Wszechprawosławnego, cz. I, WPAKP 11 (312) 2015, s.15-16.

4 Katalog zagadnień ustalony przez I Konferencję Ogóloprawosławną na Rodos (1961) zob. T. Kałużny, dz. cyt. s. 391-396. Proponowany katalog tematów dotyczył bardzo szerokiego spektrum nauki i życia Kościoła, poczynając od spraw katechetycznych, poprzez naukę Kościoła, spraw etycznych i współczesnego funkcjonowania Prawosławia. W rezultacie w kolejnych etapach przygotowawczych katalog tematów został mocno zmieniony i zredukowany
}

dokumenty były przesyłane do analizy i ewentualnych poprawek do Sobów lub Synodów poszczególnych lokalnych Kościołów. Ostateczna forma dokumentu, który miał być przedłożony Soborowi wraz z uwzględnieniem poprawek była rozpatrywana i zatwierdzane przez Ogólnoprawosławną Konferencję Przedsoborową.

Pierwsze spotkanie Międzyprawosławnej Komisji Przygotowawczej miało miejsce w dniach 16-28 listopada 1971 r. Komisja przestudiowała nadesłane opracowania poszczególnych tematów z Kościołów lokalnych i stwierdziła, że materiał jest zbyt obszerny i poleciła I Ogólnoprawosławnej Konferencji Przedsoborowej gruntowną rewizję tematów. I Ogólnoprawosławna Konferencja Przedsoborowa odbyła się w dniach 21-28 listopada 1976 r. w Chambésy ${ }^{5}$. Konferencja przyjęła szereg postanowień, które w praktyczny sposób podchodziły do zadań i przebiegu przyszłego Soboru. Jednak najistotniejszym była weryfikacja zagadnień, którymi powinien zająć się w przyszłości Sobór. Pierwotnie przyjęty plan tematów (na Rodos w 1961 r.) okazał się zbyt obszernym i skomplikowanym. W rezultacie gruntownej weryfikacji tematów Konferencja ustaliła 10 zagadnień na temat których wypowie się przyszły Sobór:

1. Diaspora Prawosławna.

2. Autokefalia i sposób jej ogłoszenia.

3. Autonomia i sposób jej ogłoszenia

4. Dyptychy.

5. Zagadnienie nowego kalendarza

6. Przeszkody w zawieraniu związków małżeńskich.

7. Przystosowanie przepisów kościelnych dotyczących postu.

8. Relacje Kościołów prawosławnych z całym światem chrześcijańskim.

9. Prawosławie wobec ruchu ekumenicznego.

10. Wkład lokalnych Kościołów prawosławnych w realizację chrześcijańskich ideałów pokoju, wolności, braterstwa i miłości miedzy narodami oraz zniesienie dyskryminacji rasowej.

Zgodnie z zaleceniem, jakie przyjęto na tejże Konferencji aby Sobór trwał stosunkowo krótko, należało wcześniej tematy opracować i uzyskać jednomyślność poszczególnych lokalnych Kościołów prawosławnych co do ich treści. Tak więc od roku 1976 rozpoczął się proces opracowywania wyżej wymienionych 10 punktów.

Opracowanie pierwszych dwóch tematów które stały się oficjalnymi dokumentami dla przyszłego Soboru miało miejsce w 1982 r. w czasie II Ogólnoprawosławnej Konferencji Przedsoborowej, która przebiegała w dniach 3-12 września 1982 r. w Chambésy ${ }^{6}$. Konferencja zajęła się trze-

Znacząca rozpiętość czasowa pomiędzy spotkaniem Komisji Przygotowawczej w 1971 r. i I Ogólnoprawosławnej Konferencji Przedsoborowej, która miała miejsce w 1976 r. była prawdopodobnie spowodowana śmiercią patriarchy Atenagorasa, która nastąpiła w 1972 r.

6 Przedstawicielami PAKP na tym spotkaniu byli: biskup Białostocki i Gdański Sawa, jako przewodniczący delegacji, oraz ks. Aleksy Semeniuk i dr Jan Anchimiuk. Na temat udziału PAKP w procesie przygotowawczym zob. A. Kuźma, Udział Polskiego Autokefalicznego Kościoła Prawosławnego w przygotowaniach Soboru Wszechprawosławnego [w:] Przed Soborem Wszechprawosławnym, Kraków 2016, s. 151-168. Red. T. Kałużny i Z. Kijas. 
ma spośród 10 tematów przedłożonych na Sobór: 1) Zagadnienie nowego kalendarza, 2) Przeszkody w zawarciu zwiazku matżeńskiego i 3) Przystosowanie przepisów kościelnych dotyczacych postu. Dwa pierwsze tematy zostały opracowane i Konferencja przyjęła treść dokumentów jako projekty na przyszły Sobór ${ }^{7}$. Nie zdołała jednak wypracować wspólnego stanowiska wobec trzeciego tematu. $Z$ tego też względu ten temat, został odesłany do Komisji przygotowawczej $\mathrm{w}$ celu ponownego przeanalizowania zagadnienia.

Trzecia Ogólnoprawosławna Konferencja Przedsoborowa odbyła się w dniach 28 października - 6 listopada 1986 r. Poprzedzona była zebraniem Komisji przygotowawczej w lutym tego samego roku. Komisja przygotowała projekt regulaminu określający rolę i zadania dwóch ważnych organów w procesie przygotowawczym tj.: 1) Ogólnoprawosławnej Konferencji Przedsoborowej (jako zatwierdzającego organu) i 2) Miedzyprawosławnej Komisji Przygotowawczej (jako organu przygotowującego projekty dokumentów). Ponadto opracowała regulamin i określiła zadania Sekretariatu do spraw przygotowań do Wielkiego i Świętego Soboru Kościoła Prawosławnego. Ponadto w lutym 1986 r. na spotkaniu Komisji przygotowawczej zostały opracowane dokumenty dotyczące kolejnych 4 zagadnień soborowych. Spotkanie III Ogólnoprawosławnej Konferencji Przedsoborowej okazało się bardzo efektywnym. Konferencja zatwierdziła regulamin funkcjonowania organów przygotowawczych, przyjęła i zatwierdziła kolejne cztery dokumenty spośród tematów soborowych 1) Znaczenie postu i jego zachowanie dzisiaj, 2) Relacje Kościoła prawostawnego z całym światem chrześcijańskim, 3) Kościót prawostawny a ruch ekumeniczny, 4) Wktad Kościoła prawostawnego $w$ realizacje pokoju, sprawiedliwości, wolności, braterstwa i mitości między narodami oraz zniesienie dyskryminacji rasowej i innych.

Pozostałe cztery tematy: 1) Diaspora prawostawna, 2) Autokefalia i sposób jej ogłaszania, 3) Autonomia i sposób jej ogłaszania i 4) Dyptychy, okazały się dość trudnymi w przygotowaniach i były obiektem debat Komisji przygotowawczych w 1990 r. i 1993 r. Metropolita Damaskinos, dyrektor Sekretariatu do Spraw Przygotowań Soboru, w 1993 r. przedstawił raport dotyczący czterech tematów, którymi zajmie się IV Ogólnoprawosławna Konferencja Przedsoborowa ${ }^{9}$. W dokumencie zostały zarysowane rozbieżności, które zostały wyrażone w raportach nadesłanych do Sekretariatu przez wszystkie lokalne Kościoły prawosławne odnoszące się do czterech wyżej wspomnianych tematów. Komisja przygotowawcza zdołała jednak częściowo opracować dokument dotyczący nadawania autonomii dla lokalnego Kościoła.

\footnotetext{
Tłumaczenie na j. polski tych dokumentów zob. T. Kałużny, dz. cyt. s. 398-401

8 Tłumaczenie na j. polski: tamże, s. 400-429

Raport ten został opublikowany w formie maszynopisu w trzech językach oficjalnych. W archiwach Warszawskiej Prawosławnej Metropolii pozostaje thumaczenie na j. rosyjski: Doklad o sovpadienijah i rashoždienijah po četyrem temam poviestki dnia IV Vsepravoslavnogo Predsobornogo Sovieŝanija,, Chambésy 1987 g.
}

Prace nakierowane do zwołania Soboru po spotkaniu Komisji przygotowawczej w 1993 r. znacząco zwolniły tempa. Przyczyną był konflikt jaki zaistniał między Patriarchatem Moskiewskim i Patriarchatem Konstantynopola odnośnie do autonomii Kościoła prawosławnego w Estonii. Komisja Przygotowawcza zdołała spotkać się na przełomie lutego i marca 1999 r. nie pojęto natomiast żadnych istotnych decyzji. Duży wpływ na zmniejszenie intensyfikacji przygotowań miała również ciężka choroba, sekretarza do spraw przygotowań do Soboru, metropolity Damaskinosa, która w 2000 r. sprawiła, że metropolita Szwajcarii do końca swoich dni nie odzyskał właściwej sprawności ${ }^{10}$.

W 2003 r. na katedrę Metropolii Szwajcarii został powołany nowy metropolita Jeremiasz (Kaliguris). Wkrótce też zajął się sekretariatem do spraw przygotowań do Wszechprawosławnego Soboru. Jednak dopiero w 2009 r. możliwym okazało się zwołanie IV Ogólnoprawosławnej Konferencji Przedsoborowej. Konferencja ta odbyła się w czerwcu 2009 r. gdzie przyjęto i podpisano dokument: Prawostawna Diaspora, jak też Regulamin funkcjonowania Zgromadzeń Episkopalnych w prawostawnej Diasporze. Zagadnienie diaspory pomimo pewnych uregulowań przyjętych przez wyżej wspomnianą Konferencję, jak też później przez Sobór 2016 r. nadal pozostaje ważnym i żywym tematem współczesnego Prawosławia.

W lutym 2011 r. została zwołana Międzyprawosławna Komisja Przygotowawcza, która starała się rozwikłać problem Nadawania autokefalii i ustalenia jednego, akceptowanego przez wszystkich Dyptychu. Spotkanie to nie przyniosło konkretnych rezultatów, chociaż zagadnienie Nadawania autokefalii zostało znacząco opracowane. Przełomowym wydarzeniem w przygotowaniach do zwołania Soboru okazała się Synaksa zwierzchników lokalnych autokefalicznych Kościołów prawosławnych, która miała miejsce w marcu 2014 r. $^{11}$. Na spotkaniu tym określono datę przyszłego Soboru na dzień Pięćdziesiątnicy 2016 r. Bardzo ważnym przedsięwzięciem było powołanie Specjalnej Komisji w celu zweryfikowania i uaktualnienia już przyjętych dokumentów na II i III Konferencji Ogólnoprawosławnej w 1982 i $1986 \mathrm{r}$.

Weryfikacja i uaktualnienie wcześniej przyjętych dokumentów było naturalną potrzebą, która wynikała z upływu czasu i dezaktualizacji niektórych treści zawartych w tych opracowaniach. Komisja Specjalna spotykała się trzy razy pod przewodnictwem metropolity Pergamonu Jana (Ziziulasa) w przedziale od września 2014 r. do kwietnia 2015 r. W rezultacie prac Komisji możliwym okazało się zwołanie V Ogónoprawosławnej Konferencji Przedsoborowej w dniach 10-17 października 2015 r. Konferencja pracowała pod przewodnictwem najpierw metropolity Pergamonu Jana (Ziziulasa), następnie zaś pod przewodnictwem metropolity Francji Emanuela (Adamakisa).

\footnotetext{
10 Metropolita Damaskinos (Papandreu) Zmarł w Genewie w 2011 r. Jego charyzma i osobiste zaangażowanie sprawiały, że prace chociaż powoli, lecz konsekwentnie posuwały się do przodu.

11 Zob. Decyzja Zwierzchników Cerkwi Prawosławnych, WPAKP 2014, nr 4 (293), s. 3.
} 
Konferencja wniosła poprawki i jednogłośnie przyjęła trzy dokumenty przygotowane przez Komisję: 1) Autonomia i sposób jej ogłaszania; $\mathrm{z}$ dwóch dokumentów opracowanych w 1986 r. Relacje Kościoła prawostawnego z całym światem chrześcijańskim i Kościót prawosławny a ruch ekumeniczny, powstał jeden łączący dwa teksty: 2) Relacje Kościoła prawostawnego z pozostalym światem chrześcijańskim. Trzeci tekst to: 3) Ważność postu i jego wypetniane dzisiaj. Temat, który został sformułowany na III Ogólnoprawosławnej Konferencji Przedsoborowej w 1986 r.: Wkład Kościoła prawostawnego w realizacje pokoju sprawiedliwości, wolności, braterstwa i miłości między narodami oraz zniesienie dyskryminacji rasowej i innych, został przez Komisję Specjalną przeformułowany, jednak nie uzyskał pełnej akceptacji uczestników V Ogólnoprawosławnej Konferencji Przedsoborowej. Rozbieżności dotyczyły interpretacji pewnych szczegółów i sformułowań ${ }^{12}$.

W swoim zamyśle V Ogólnoprawosławna Konferencja Przedsoborowa była zaplanowana jako ostatni etap przygotowań do przyszłego Soboru. Dokumenty opracowane i zatwierdzone przez poszczególne Konferencje Przedsoborowe, byłyby solidnymi projektami, które w dość krótkim czasie mogły być rozpatrzone i przyjęte przez Sobór. Natomiast dokumenty, które pozostały w fazie przygotowawczej, miały być opracowane przez sam Sobór, jako najwyższą instancje i następnie zatwierdzone. Biorąc pod uwagę jednak fakt, że Sobór planowany był jako wydarzenie, które powinno ograniczać się do 3-5 dni, w opinii większości delegatów V Konferencji Przedsoborowej, nie należy tą pracą obarczać Ojców soborowych, ze względu na brak czasu potrzebnego dla opracowania tych dokumentów i uzyskania powszechnej zgody. W takim wypadku należałoby przypuszczać, że jeszcze przed zwołanie Soboru (tj. przed czerwcem 2016 r.) będą miały miejsce spotkania przedstawicieli lokalnych Kościołów prawosławnych na różnym szczeblu w celu przygotowania brakujących dokumentów.

Takim spotkaniem na najwyższym szczeblu okazała się Synaksa zwierzchników wszystkich lokalnych Kościołów prawosławnych, która odbyła się w dniach 21-28 stycznia 2016 r. w Chambésy ${ }^{13}$. Na spotkanie przybyło jedenastu zwierzchników lokalnych Kościołów autokefalicznych, natomiast trzech przysłało swoich przedstawicieli $^{14}$. Na spotkaniu tym podjęto szereg ważnych decyzji. Przyjęto poprawki do nie podpisanego na V Konferencji Przedpoborowej dokumentu. W swej ostatecznej wersji dokument otrzymał tytuł: Misja Kościoła prawosławnego we wspótczesnym świecie. Wkład Kościoła prawostawnego $w$ osiagnięcie pokoju, sprawiedliwości, wolności, braterstwa i miłości między narodami oraz zniesienie dyskrymi-

\footnotetext{
12 Zob. A. Kuźma, V Wszechprawosławna Konferencja Przedsoborowa, WPAKP 2015, nr 12 (313), s. 15

13 Zob. bp Jerzy (Pańkowski), Synaksa zwierzchników Lokalnych Cerkwi Prawosławnych. Chambesy (21-28 stycznia 2016 r.), WPAKP 3 (316) 2016, s. 4-5.

14 Na spotkanie nie przybył Patriarcha Antiochii Jan X, Arcybiskup Grecji Hieronim, oraz z powodów zdrowotnych na spotkanie nie dotarł Metropolita Warszawski i całej Polski Sawa. Przedstawicielem PAKP na tym spotkaniu był biskup siemiatycki Jerzy.
}

nacji rasowej i innej. Przyjęto rozszerzony tekst dokumentu dotyczącego małżeństwa. Tytuł dokumentu w nowej wersji brzmiał: Sakrament matżeństwa i przeszkody w jego zawarciu ${ }^{15}$. Przyjęto Regulamin Świętego i Wielkiego Soboru Wszechprawosławnego, określający liczbę biskupów i osób nie będących biskupami, którzy mogą przybyć na Sobór z poszczególnych Kościołów lokalnych. Powołano do życia Sekretariat Soboru Wszechprawosławnego. W jego skład weszło po jednym przedstawicielu z każdego lokalnego Kościoła. Uczestnicy Synaksy, przyjęli Komunikat w który informowali o podjętej decyzji zwołania Soboru w dniach 16-27 czerwca 2016 r. na wyspie Krecie. Ponadto w Komunikacie ogłoszono tytuły wszystkich dokumentów, które przygotowane zostały jako projekty na zaplanowany Sobór ${ }^{16}$.

Przed zwołaniem Soboru nie było już spotkań na najwyższym szczeblu, natomiast dwa razy spotykali się członkowie Sekretariatu. Pierwsze spotkanie odbyło się w Chambésy w dniach 29-30 marca 2016 r. Przedstawicielem PAKP na tym zebraniu był biskup siemiatycki Jerzy. Członkowie sekretariatu podjęli decyzję o stworzeniu oficjalnej witryny internetowej, która dawałaby wgląd dla szerokiej publiczności do projektów dokumentów na planowany Sobór ${ }^{17}$. Drugie spotkanie Sekretariatu miało miejsce na Krecie i przebiegało w dwóch punktach wyspy w Heraklionie, gdzie planowano św. Liturgię rozpoczynającą obrady Soboru i w Kolimbari niedaleko Chania, gdzie miały przebiegać obrady Soboru. Ustalono wiele szczegółów przebiegu Soboru i członkowie Sekretariatu wysoko ocenili działania komitetu organizacyjnego, który pracował pod przewodnictwem Metropolity Francji Emanuela (Adamakisa). Na spotkaniu zabrakło przedstawicieli Patriarchatu Aleksandryjskiego, Jerozolimskiego i Kościoła Albanii. Przedstawicielem PAKP był ks. Andrzej Kuźma ${ }^{18}$.

\section{Problem nieobecności czterech Kościolów}

Kilka tygodni przed rozpoczęciem planowanego Soboru, prawosławny świat posuszyła nieoczekiwana deklaracja kilku lokalnych Kościołów w której ogłaszano odmowę wzięcia udziału w planowanym Soborze. Kościołem, który wcześniej uzależniał swoje przybycie na Sobór od rozwiązania kwestii jurysdykcji Kataru był Kościół antiocheński ${ }^{19}$. Natomiast zaskakującymi deklaracjami były

\footnotetext{
Dokument został rozszerzony i uzupełniony o nowy rozdział: Prawosławne małżeństwo. Nowy fragment dokumentu został zaproponowany przez przedstawicieli Patriarchatu moskiewskiego.

16 Treść Komunikatu, WPAKP, 3 (316) 2016, s. 5

Zob. Posiedzenie Sekretariatu Soboru Wszechprawosławnego, WPAKP 5 (318) 2016, s. 5.

18 Zob.A. Kuźma, Spotkanie Sekretariatu Soboru Wszechprawosławnego, WPAKP 6 (319) 2016, s. 3.

19 Problem jurysdykcji kościelnej na terytorium Kataru zaistniał w 2012 r. Jest to problem nieco złożony i wymagałby dłuższego opisu. Patriarchat Jerozolimski włączył do swojej jurysdykcji parafię prawosławną, która wcześniej znajdowała się pod duchową opieką Patriarchatu Antiochii na terytorium Kataru. Takie działanie spowodowało przerwanie łączności eucharystycznej miedzy tymi dwoma Kościołami. W czasie drugiego spotkania Specjalnej Komisji w dniach 15-21 lutego 2015 w Chambésy, delegacja Patriarchatu antiocheńskiego przedstawiła list Patriarchy Jana
} 
decyzje pozostałych trzech Kościołów. Jako pierwszy informacje o swoim odwołaniu wzięcia udziału w Soborze ogłosił Kościół bułgarski. Informacja ta pojawiła się 1 lipca. Następnie 6 lipca podobną deklarację ogłosił Kościół antiocheński. Kolejnym Kościołem odnawiającym przyjazdu na Sobór był Kościół gruziński, który podał tę informację 10 lipca. Trzy dni później 13 lipca, na pięć dni przed rozpoczęciem Soboru podobną deklarację ogłosił Kościół rosyjski. W ten sposób cztery ważne Kościoły spośród czternastu, odmówiły swego udziału w obradach. Powody odmowy wzięcia udziału z zebraniu były różne. W niniejszym opracowaniu nie będę podejmował tego tematu, jak też oceny decyzji powziętych przez wyżej wymienione Kościoły. Nadmienić jednak należy, że wszystkie te wyżej wymienione Kościoły od samego początku brały udział w długim procesie przygotowawczym do Soboru. Wszystkie one wniosły znaczący wkład w przygotowanie projektów dokumentów na Sobór. Zwłaszcza Kościół rosyjski, zarówno w latach 80-tych jak i w ostatnim etapie przygotowawczym wniósł ogromny merytoryczny wkład w przygotowanie dokumentów.

\section{Rozpoczęcie Soboru}

Oficjalne rozpoczęcie Soboru miało miejsce w dniu 19 czerwca celebracją św. Liturgii w katedralnej świątyni Heraklionu pod wezwaniem św. apostoła Minasa. Nabożeństwo zostało odprawione pod przewodnictwem Patriarchy ekumenicznego Bartolomeusza $\mathrm{z}$ udziałem wszystkich zwierzchników autokefalicznych lokalnych Kościołów prawosławnych przybyłych na Sobór. Należy jednak zaznaczyć, że jeszcze przed rozpoczęciem Soboru od 9 czerwca w pomieszczeniach Prawosławnej Akademii Krety obradowała Komisja do spraw Orędzia Wielkiego i Świętego Soboru. Zadaniem komisji było przygotowanie projektu tekstu Orędzia, które Sobór przyjąłby w czasie swoich obrad. Komisja pracowała pod przewodnictwem metropolity Francji Emanuela. W skład Komisji wchodziło dziesięciu członków, pochodzących ze wszystkich lokalnych Kościołów prawosławnych. Ze strony PAKP członkiem komisji był biskup siemiatycki Jerzy.

Plenarne obrady Soboru zostały zainaugurowane w dniu 20 czerwca. Wszystkie sesje Soboru odbywały się w pomieszczeniach Prawosławnej Akademii Krety w miejscowości Kolimbari niedaleko miasta Chania. Sobór obradował pod przewodnictwem patriarchy Ekumenicznego Bartolomeusza. Patriarcha wraz z pozostałymi zwierzchnikami zasiadał za półkolistym stołem prezydialnym według porządku dyptychów. Pozostali uczestnicy Soboru, biskupi, duchowni i świeccy zostali umiejscowieni naprzeciwko prezydium. Obrady rozpoczęły się przemówieniem Patriarchy Konstantynopola na temat zadania stojącego przed rozpoczynającym się Soborem. Następnie pozostali zwierzchnicy według porządku dyptychów wyrazili swoje

X, informujący o tym, że jeśli konflikt nie zostanie rozwiązany Kościół antiocheński nie weźmie udziału w planowanym Soborze. opinie na ten sam temat ${ }^{20}$. W ten sposób rozpoczęła się praca nad przygotowanymi dokumentami. Należy nadmienić, że w czasie trwania Soboru głos zabierać mogli jedynie biskupi. Pozostali uczestnicy Soboru posiadali rolę doradczą.

\section{Część II Dokumenty Soboru}

Z pewnością czynnikiem, który stanowi o rezultatach Soboru są jego dokumenty i nauczanie, które tam zostało sformułowane. Dokumenty, które zostały przyjęte na Soborze w 2016 r. na Krecie można zaszeregować do trzech zasadniczych grup ${ }^{21}$ :

A) Dokumenty o charakterze ogólnym:

1) Orędzie Świętego i Wielkiego Soboru Kościoła Prawostawnego.

2) Przesłanie Świętego i Wielkiego Soboru Kościoła Prawosławnego do prawosławnego ludu i wszystkich ludzi dobrej woli.

B) Dokumenty tematyczne, które odnoszą się do wewnętrznego życia Kościoła:

1) Ważność postu i jego wypetnienie dzisiaj.

2) Sakrament malzeństwa i jego przeszkody.

3) Autonomia i sposób jej ogłaszania.

4) Prawostawna diaspora.

C) Dokumenty tematyczne, które odnoszą się do zewnętrznego życia Kościoła.

1) Relacje Kościoła prawostawnego z pozostatym światem chrześcijańskim.

2) Misja Kościoła prawosławnego we wspótczesnym świecie. Wkład Kościoła prawosławnego w osiagnięcie pokoju, sprawiedliwości, wolności, braterstwa i mitości między narodami oraz zniesienie dyskryminacji rasowej i innej.

\section{A. Dokumenty o charakterze ogólnym}

\section{Orędzie Świętego i Wielkiego Soboru Kościoła Prawosławnego.}

Dokument ten jak już zostało wspomniane wyżej został opracowany przez członków Komisji, która zebrała się tuż przed rozpoczęciem obrad Soboru, aby stworzyć projekt Orędzia. Stanowi on swego rodzaju wstęp do kolejnych dokumentów poruszając wiele kwestii współczesnego życia Kościoła prawosławnego. W swoich pierwszych wyrażeniach w Orędziu przyzywane jest Imię Boże, które wyraża się w wierze w Świętą Trójcę. Autorzy dokumentu zwracają uwagę, że Orędzie będąc kierowane przede

20 Wszystkie mowy wygłoszone przez Głowy lokalnych Kościołów prawosławnych dostępne są na witrynie internetowej www.holycouncil. com

${ }_{21}$ Takie podział jest umowny. Wydaje mi się, że jest on właściwy dla naszych rozważań i pewnego usystematyzowania w celu przeanalizowania tych dokumentów. 
wszystkim do wiernych Kościoła prawosławnego, jest również kierowane do innych ludzi: „Zatem jednymi ustami i jednym sercem kierujemy słowo $<$ naszej nadziei $>$ nie tylko do dzieci naszego Kościoła, lecz do każdego człowieka, <który jest daleko i blisko>"'22 (Wstęp). Dokument składa się z 8 rozdziałów, podzielonych na 20 punktów, odnoszących się w pewien sposób do zagadnień o charakterze doktrynalnym jak też dotykających współczesnego świata. Ojcowie soborowi podkreślają, że Kościół prawosławny ,jest autentyczną kontynuacją jednego świętego, powszechnego i apostolskiego Kościoła, tak jak jest On wyznawany w Symbolu Wiary i potwierdzany w nauczaniu Ojców Kościoła" (p.2). Powyższe stwierdzenie należy rozumieć w ten sposób, że Kościół prawosławny rzeczywiście jest tym Kościołem, który zachowuje autentyczną i nie zmienioną prawdę i Tradycję apostolską, pozostając Kościołem Jedynym. W ten sposób inni chrześcijanie „oddalili się od Niego" (p.20), tj. od Kościoła Jedynego. Takie dogmatyczne stwierdzenie jest absolutnie zgodne z eklezjologią Kościoła prawosławnego, nie należy jednak interpretować go jako kościelnego ekskluzywizmu ${ }^{23}$.

Wiele miejsca poświęcono życiu Kościoła we współczesnym świecie. Ojcowie soborowi nawołują do potrzeby ciągłego głoszenia Ewangelii i „ponownej reewangelizacji ludu Bożego we współczesnych zlaicyzowanych społeczeństwach oraz ewangelizacji tych, którzy jeszcze nie poznali Chrystusa" (p.6). Podkreślają, że rodzina oparta na małżeństwie pozostaje ,jedyną gwarancją rodzenia i wychowania dzieci, zgodnie z planem Bożej ekonomii, stanowiąca <mały Kościół〉” (p.7). Współczesny kryzys małżeństwa i rodziny spowodowany jest niewłaściwym i egocentrycznym pojmowaniem wolności. Zsekularyzowany model edukacji jest wielkim wyzwaniem dla Kościoła i wywołuje jego zatroskanie (p.9).

W wielu zsekularyzowanych środowiskach Kościół jest postrzegany jako konserwatywny organizm sprzeciwiający się postępowi cywilizacyjnemu i naukowemu. Ojcowie Soboru, uważają, że taka klasyfikacja jest nieprawdziwa i niesprawiedliwa. „Wszystko, co powoduje zmiany w sposobie życia człowieka, wymaga od niego rozeznania, ponieważ oprócz istniejących dobrodziejstw, takich jak ułatwienie życia codziennego, skuteczne leczenie poważnych chorób (...), mamy również do czynienia $\mathrm{z}$ negatywnymi konsekwencjami postępu naukowego" (p.11). Entuzjazm, który jest wywołany badaniami i osiągnięciami w dziedzinie bioetyki, genetyki i neurofizjologii mózgu, niewłaściwie zastosowany może wywołać

\footnotetext{
Wszystkie cytowania w j. polskim dokumentów Soboru 2016 na Krecie pochodzą z tłumaczenia zawartego w Cerkiewnym Wiestniku 4/2016. Należy nadmienić, że redaktorzy Wiestnika, tak jak stanowi on źródło informacyjne dla wiernych Kościoła prawosławnego, uważali za stosowne posługiwanie się w swoim thumaczeniu słowem „Cerkiew” zamiast „Kościól”. W niniejszym opracowaniu, tak jak nosi ono charakter naukowy zamiast wyrażenia „Cerkiew” będę stosował określenie „Kościół”.

23 Zagadnienie to wymagałoby dalszego omówienia i analizy w kontekście współczesnej problematyki relacji międzychrześcijańskich. Powyższa kwestia będzie powracać jeszcze w dokumencie Soboru Relacje Kościoła prawosławnego z pozostałym światem chrześcijańskim.
}

poważne dylematy antropologiczne i moralne. „Istnieje niebezpieczeństwo jego (człowieka) zamiany w maszynę biologiczną, w bezosobową jednostkę społeczną lub aparat kontrolowanego myślenia" (p.12). Człowiek jest boskiego pochodzenia, stwierdzają Ojcowie, stworzony na obraz i podobieństwo Boże. Świadczy to o jego wyjątkowym powołaniu.

W dobie społeczeństwa konsumpcyjnego, które ukierunkowane jest na posiadanie i indywidualizm dokument zwraca uwagę na umiejętność zachowania ascezy, która nie jest domeną wyłącznie życia monastycznego. Chęć posiadania, nienasycenie, egoizm, skłonność do zaborczości stały się przyczynami kryzysu ekologicznego. W jego konsekwencji następują zmiany klimatyczne, które zagrażają środowisku naturalnemu „naszemu wspólnemu domowi”. Dlatego też stwierdza się dalej, „Zerwanie związków człowieka ze stworzeniem jest wypaczeniem autentycznego wykorzystania stworzenia Bożego" (p.14). Kościół, zawsze z sakramentalnym szacunkiem odnosił się do stworzenia Bożego. Słowa wyjęte ze św. Liturgii: „To co Twoje, od Twoich, Tobie przynosimy, za wszystkich i za wszystko", świadczą o eucharystycznej więzi człowieka ze stworzeniem.

W szóstym rozdziale dokumentu, który jest zatytułowany: Kościót w obliczu globalizacji, skrajnych zjawisk przemocy oraz migracji, poruszonych zostało wiele wątków współczesnego życia i zaangażowania Kościoła. Nie sposób jest odnieść się do nich wszystkich, warto jednak zwrócić uwagę na najważniejsze $\mathrm{z}$ nich. Zagrożeniem, uważają Ojcowie soborowi jest problem postępującej globalizacji. Nazywają ten proces „zrównującą i bezosobową unifikacją" i jako alternatywę proponują „ochronę tożsamości narodów i wzmocnienie lokalnych tradycji" (p.15). Mowa też jest o apolitycznym ustosunkowaniu się Kościoła w państwie, tj. nie angażowaniu się Kościoła w politykę, natomiast Kościół ma prawo i obowiązek stawać w obronie człowieka wobec Państwa, kiedy zachodzi taka potrzeba. Państwo powinno zagwarantować swobodę religijną swoim obywatelom, bez względu na wyznawaną przez nich religię: „Fundamentalnym prawem człowieka jest ochrona zasady wolności religijnej we wszystkich jej przejawach, czyli wolności sumienia, wiary, kultu oraz wszystkich innych przejawów wolności religijnej, czy to prywatnie, czy we wspólnocie"24 (p.16). Fundamentalizm religijny, który przejawia się $\mathrm{w}$ wielu religiach i miejsca współczesnego świata, Ojcowie soborowi nazywają ,przejawem chorej religijności”. Jako alternatywne działanie ukazują na podążanie w swoim działaniu za przykładem Chrystusa: „Prawdziwy chrześcijanin, idąc za przykładem Ukrzyżowanego Pana, poświęca się, ale nie wymaga poświęceń i z tego powodu jest najsurowszym sędzią jakiegokolwiek pochodzenia fundamentalizmu" (p.17). Lekarstwem na fundamentalizm może być jedynie „szczery dialog międzyreligijny".

\footnotetext{
24 Wydaje się, że Ojcowie soborowi przedkładając zasadę równości religii w Państwie, dalecy są od idei tzw. „symfonii”, która w chrześcijańskim Cesarstwie rzymskim, szczególnie we wschodniej części była uważana za właściwy model współżycia Kościoła i Państwa.
} 
Odnosząc się do zaistniałego konfliktu na Bliskim wschodzie, autorzy dokumentu wyrażają niepokój z powodu prześladowania chrześcijan i przemocy, która jest wobec nich stosowana. Ale również wyrażają swoją troskę o prześladowania każdego innego człowieka z powodów religijnych jak też „Piętnuje niszczenie świątyń, symboli religijnych i zabytków kultury" (p.18). W dokumencie wyraźnie nawołuje się do okazywania pomocy tym, którzy zostali zmuszeni do opuszczenia swoich domów i z tego powodu ponoszą wiele cierpień. Wskazuje się na słowa Ewangelii, które zobowiązują nas do takiego postępowania: „Byłem głodny i daliście mi jeść, byłem spragniony i napoiliście mnie, byłem przybyszem i przyjęliście mnie (...)" (Mt 25, 35-36). Dokument, który został podpisany przez wszystkich obecnych tam biskupów wskazuje: „Wzywamy władze polityczne, prawosławnych wiernych i wszystkich pozostałych obywateli państw, w których schronili się uchodźcy i do których nadal podążają, aby okazali im wszelką możliwą pomoc, pomimo własnego niedostatku" (p.19).

W swoich końcowych wyrażeniach w dokumencie jeszcze raz zawarto potwierdzenie świadczące o woli Kościoła prawosławnego do trwania w dialogu, podkreśla się jednak ,w szczególności zaś do dialogu z chrześcijanami innych wyznan" (p.20). Dialog ten nie może zakładać pewnego „kompromisu w sprawach wiary”. Tj. autorzy Orędzia wskazują, że dogmatyczna nauka Kościoła jest niezmienną i nie może ona być obiektem ingerencji w celu osiągnięcia pewnego kompromisu wiary. Zasadą dialogu pozostaje dawanie świadectwa o swojej wierze, gdzie zasadniczym motywem pozostaje ewangeliczne: „przyjdź i zobacz” (J 1,46), że „Bóg jest miłością” (J. 4,8).

Orędzie Świętego i Wielkiego Soboru Kościoła Prawosławnego, jest dokumentem bogatym $\mathrm{w}$ treść i zawiera znacznie więcej ważnych elementów na które warto byłoby zwrócić uwagę. $\mathrm{Z}$ powodu jednak braku miejsca wskaże na jeszcze dwa istotne punkty. W rozdziale pierwszym, Kościót: Ciało Chrystusa, obraz Świętej Trójcy, wskazuje się na wiele ważnych czynników teologicznych i dogmatycznych dotyczących życia Kościoła prawosławnego, natomiast $\mathrm{z}$ punktu widzenia praktycznego, Ojcowie Soboru, mówią o czternastu lokalnych Kościołach autokefalicznych, które uznawane są przez ogół Prawosławia (p.5). Wyrażając się w ten sposób dokument potwierdza, że grupy, które wyłoniły się w różnych momentach historii tworząc schizmę wobec Kościoła macierzystego i które nadal trwają w separacji nie są i nie mogą stanowić Kościołów, które uznawane są przez ogół Prawosławia ${ }^{25}$.

Drugi punkt na który chciałbym wskazać jest nauczanie zawarte w zakończeniu Orędzia. Ojcowie Soboru zwracają naszą uwagę na znaczenie Eucharystii, jako „tajemnicy Bożego planu zbawienia w życiu sakramentalnym” w Kościele prawosławnym. Eucharystia, czytamy

\footnotetext{
5 Należy zaznaczyć, że nie chodzi tu o Prawosławny Kościół w Ameryce, który uznawany jest przez część prawosławnych Kościołów autokefalicznych za Kościół samodzielny, tj. autokefaliczny, przez inną część tych Kościołów zaś uznawany jest jako Metropolia Patriarchatu Moskiewskiego.
}

w dokumencie, pozostaje „niezniszczalnym i łatwo psującym się pożywieniem, lecz samym Życiodajnym Ciałem Pana, Chlebem niebiańskim". Eucharystia w Prawosławiu rzeczywiście pozostaje w centrum uwagi i jest źródłem i znakiem przynależności do Kościoła prawosławnego. Przywodząc cytaty z pism św. Ignacego Antiocheńskiego i św. Ireneusza z Lyonu, Ojcowie powtarzają, że jest Ona potwierdzeniem naszego nauczania.

\section{Przesłanie Świętego i Wielkiego Soboru Kościo-} la Prawosławnego do prawosławnego ludu i wszystkich ludzi dobrej woli.

Dokument, który w swoim tytule został określony jako Przestanie Świętego i Wielkiego Soboru, podobnie jak poprzedni tekst, nie był obiektem przygotowań Komisji i Konferencji przedsoborowych. Tekst powstał z inicjatywy arcybiskupa Tirany i całej Albanii Anastazego, jako stosunkowo krótkie przesłanie do szerokiego grona odbiorców. Tekst w swojej pierwotnej formie został opracowany przez zwierzchnika Kościoła Albanii, natomiast uzupełniony i w nieznaczny sposób poprawiony, został przyjęty i ogłoszony przez całe Zebranie na Krecie. Powyższe Przesłanie zostało w uroczysty sposób odczytanie w czasie św. Liturgii kończącej obrady Soboru, która miała miejsce 26 czerwca w katedrze pod wezwaniem św. apostołów Piotra i Pawła w Chania.

Dokument już w samym tytule w wyraźny sposób wskazuje, że jest słowem adresowanym do „prawosławnego ludu i wszystkich ludzi dobrej woli”, tzn. wskazuje, że jest kierowany zarówno do prawosławnych, jak też osób, które identyfikują się z innymi wyznaniami chrześcijańskimi lub też innymi religiami, czy też są osobami nie wierzącymi, lecz napełnionymi chęcią czynienia dobra. Zaznacza się, że Sobór odbył się w dniach poprzedzających święto Zesłania Ducha Świętego na Apostołów na wyspie Krecie, która była miejscem działalności i misji apostoła Pawła i jego ucznia Tytusa. Przesłanie jest znacznie krótsze od Orędzia, składa się z dwunastu punktów, poprzedzonych wstępem. Natomiast jeśli chodzi o treść tego dokumentu, to należy stwierdzić, że jest ona bardzo podobna do poprzedzającego tekstu. W zasadzie porusza te same zagadnienia, ale w skróconej formie. Znajdujemy też kilka istotnych punktów, które nie występują w Orędziu. Do tych ważnych punktów należałoby zaliczyć stwierdzenia, które wskazują na cel odbywającego się Soboru. Otóż zwołanie Soboru nie jest związane z zaistnieniem jakiegoś problemu teologicznego, czy też nowych regulacji kanonicznych. Ojcowie Soborowi zgodnie stwierdzają że: „priorytetem Świętego i Wielkiego Soboru było ogłoszenie jedności Kościoła prawosławnego. Oparta na św. Eucharystii i sukcesji apostolskiej biskupów, istniejąca jedność musi być wzmacniana i przynosić nowe owoce" (p. 1). W ten sposób dowiadujemy się, że ukazanie jedności całego Prawosławia było nadrzędną wartością, która kierowała hierarchami w okresie przygotowawczym jak też w momencie zwoływania Soboru. W jaki sposób i czy ten cel został osiągnięty, postaram się wyrazić w podsumowaniu niniejszej pracy. 
Oprócz tego ważnego wskazania, które dotyczy zwołania Soboru, należałoby zwrócić uwagę na pewne uzupełnienie dotyczące soborowości i pojmowania zagadnienia współczesnych autokefalicznych Kościołów prawosławnych. Ojcowie soborowi podkreślają, że „soborowość przenika organizację, sposób, w jaki są podejmowane decyzje i określa ich drogę" (p.1). Zauważa się, że prawosławne Kościoły autokefaliczne nie stanowią swego rodzaju federacji Kościołów, lecz stanowią Jeden, Święty, Powszechny i Apostolski Kościół.

$$
* * *
$$

Właściwe dokumenty, które zostały przyjęte i ogłoszone na Soborze były obiektem dyskusji i opracowań trwających przez wiele lat. Dyskusje, które towarzyszyły powstawianiu tych dokumentów stanowią niezwykle ciekawy materiał badawczy ukazujący atmosferę i troskę hierarchów i teologów prawosławnych o jedność Kościoła prawosławnego, ale jednocześnie wykazują żywość współczesnej problematyki ${ }^{26}$. Omawiając poszczególne dokumenty, tylko w niewielkim stopniu sięgnę do historii ich przygotowań, skupiając się bardziej na ich treści.

\section{B) Dokumenty tematyczne, które odnoszą się do wewnętrznego życia Kościoła}

\section{Ważność postu i jego wypełnienie dzisiaj}

Dokument dotyczący zagadnienia postu w swej początkowej formie został przyjęty na III Ogólnoprawosławnej Konferencji Przedsoborowej w 1986 r. Debata jednak nad tym dokumentem rozpoczęła się już na II Konferencji w 1982 r. Tytuł dokumentu jaki został określony w swej początkowej formie, brzmiał: Przystosowanie przepisów kościelnych dotyczacych postu zgodnie ze wspólczesnymi wymogami. Nazwanie w ten sposób dokumentu wskazywałoby, że intencją Konferencji Ogólnoprawosławnych było wprowadzenie pewnych modyfikacji w Tradycji Kościoła prawosławnego dotyczącej postu. Przygotowanie projektu tego dokumentu dla potrzeb Komisji zostało powierzone dla Kościoła serbskiego. Sugestie i propozycje nadesłane przez niektóre Kościoły lokalne wskazywały na potrzebą skrócenia postu przed Bożym Narodzeniem, zniesienie postu przed świętem Apostołów Piotra i Pawła, jak też mniej rygorystyczne podejście do Wielkiego po$\mathrm{stu}^{27}$. Dokument, który został przygotowany dla potrzeb Komisji jak się okazało nie zawierał takich przystosowań do współczesnych wymogów, lecz wyrażał się w terminach tradycyjnego podejścia do postu i zwracał uwagę na jego ważność i potrzebę w życiu chrześcijanina. Dlatego też w opinii części uczestników Konferencji treść przy-

\footnotetext{
26 Materiały z dyskusji i procesu opracowywania poszczególnych dokumentów w czasie Ogólnoprawosławnych Konferencji Przedsoborowych zostały opublikowane w periodykach Synodica, wydawanym przez Sekretariat do Spraw Przygotowań Wielkiego i Świętego Soboru Kościoła Prawosławnego w Chambésy k. Genewy.

27 Zob. Synodica VIII, Secretariat pour la preparation du Saint et Grande Concile de l'Eglise Orthodoxe, Chambésy- Genève 1994, s. 164
}

gotowanego dokumentu nie odzwierciedlała jego tytułu i nie rozwiązywała problemu. Dyskusja jaka wywiązała się w związku z tematem postu ukazywała dwie tendencje uczestników Konferencji: 1) reformatorską, która podkreślała potrzebę wprowadzenia zmian w tradycji i dyscyplinie postów, jak też 2) tradycyjną, wskazującą na potrzebę zachowania postów, które stanowią ważny element życia i duchowości Kościoła prawosławnego ${ }^{28}$. Przeważyły głosy opowiadające się za opcją tradycyjną, dlatego też decyzją Konferencji został zmieniony tytuł dokumentu, w ten sposób aby odzwierciedlał rzeczywistą treść: Znaczenie postu i jego zachowanie dzisiaj ${ }^{29}$.

Zgodnie z decyzją Synaksy Zwierzchników lokalnych Kościołów autokefalicznych w marcu 2014 r. wszystkie wcześniej przygotowane dokumenty zostały poddane rewizji. Dokument o poście okazał się na tyle dobrym i zadawalającym, że Komisja Specjalna, która analizowała i uzupełniała ten dokument w 2015 r. wprowadziła drobne i mało znaczące poprawki.

Dokument przyjęty na Soborze na Krecie w polskiej wersji językowej otrzymał tytuł: Ważność postu i jego wypełnienie dzisiaj. Treść dokumentu jest raczej pasterskim nawoływaniem niż kodeksem dyscyplinarnym regulującym zasady postu. Ojcowie soborowi jednoznacznie wskazują na ważność i wartość postu dla prawosławnego chrześcijanina: „Kościół prawosławny, niezmiennie podążając w ślad zarówno za apostolskimi postanowieniami, kanonami Soborów, jak i całością tradycji patrystycznej, zawsze głosił najwyższą wartość postu dla duchowego życia człowieka i jego zbawienia" (p.1). W tekście przywodzi się szereg przykładów ze Starego i Nowego Testamentu, jak też literatury patrystycznej, które podkreślają ważność i niezbędność postu w życiu duchowym człowieka. Podkreślana jest wartość duchowa postu, a nie same wyrzeczenie się pewnych produktów spożywczych: „Prawdziwy post, jako zmaganie duchowe, związany jest z nieustanną modlitwą i szczerym pokajaniem" (p.3). W dokumencie zostaje potwierdzona Tradycja Kościoła prawosławnego nawołująca do zachowywania czterech postów wielodniowych: Wielkiego postu, przed Bożym Narodzeniem, przed świętem Zaśnięcia Bogurodzicy i postu Piotrowego, jak też postów jednodniowych związanych z określonymi świętami i też postów w każdą środę i piątek (p.6). W dokumencie nie zostały zdefiniowane i ukazane konkretne produkty żywnościowe, których nie zaleca się spożywać w czasie postu, lub które można spożywać. W tej kwestii należy się słuchać Tradycji, ale również stwierdza się, że każdy Kościół lokalny według swoich warunków klimatycznych i geograficznych może samodzielnie rozwiązywać powyższe problemy (zob. p.7 i p.8). Ważną rzeczą na którą zwraca się uwagę, jest wymóg zachowywania ścisłego postu przed Eucharystią: ,Wszyscy wszakże wierni Kościoła powinni przestrzegać świętych postów i zachowywać wstrzemięźliwość od pokarmów od północy, aby

\footnotetext{
28 Zob. toczącą się dyskusję, Synodica VIII dz. cyt. s. 156-170

29 Tekst dokumentu o poście, który został przyjęty przez III Ogólnoprawosławną Konferencję Przedsoborową (1986) zob. T. Kałużny, dz. cyt. s. $402-405$.
} 
systematycznie przystępować do św. Eucharystii” (p. 9). Pościć należy również $\mathrm{w}$ znak pokajania, post może również być wyrazem nałożonej epitemii, jak też przed ważnymi wydarzeniami duchowymi jakimi są Chrzest, święcenia kapłańskie i in. (zob. p. 9).

Autorzy tekstu nie używają określeń, które wskazywały by na „obowiązkowość postu”. Tekst jest raczej zachętą i pasterskim pouczeniem o wartości duchowej postu. Nie występują wyrażenia, które sankcjonowałyby osoby nie wypełniające postu. Tradycja kanoniczna w niektórych swoich wyrażeniach bardzo surowo odnosi się do tych, którzy nie przestrzegają postu ${ }^{30}$. Ojcowie soborowi pomimo zsyłania się na Tradycję kanoniczną, nie przywodzą w dokumencie takiej dyscyplinarnej normy.

\section{Sakrament malżeństwa i jego przeszkody}

Dokument mówiący o Sakramencie małżeństwa i przeszkodach $\mathrm{w}$ jego zawarciu, jest jednym z tekstów, który w swojej pierwotnej wersji został najwcześniej opracowany. Pierwotna wersja tematu i tekstu była znacząco zawężona i brzmiała Przeszkody matżeńskie ${ }^{31}$. Stenogramy dyskusji prowadzonych w latach 80-tych ubiegłego wieku wskazują cel podjęcia tego zagadnienia. Problemy, które wyłaniają się w czasie II Ogólnoprawosławnej Konferencji Przedsoborowej w 1982 r., dotyczyły kilku punktów z których najważniejsze to: 1) możliwości zawarcia związku małżeńskiego przez osoby będące w stanie duchownym, 2) zawierania związków mieszanych wyznaniowo i 3) określenie od jakiego stopnia pokrewieństwa można zawrzeć związek małżeński.

W opinii niektórych przedstawicieli lokalnych Kościołów prawosławnych, uczestniczących w debatach w $1982 \mathrm{r}$. istnieje pasterska troska i potrzeba aby Kościół w pewnych warunkach zezwalał na zawarcie związku małżeńskiego dla osób, które są w stanie duchownym tj. dla diakonów i dla prezbitrów. Uczestnicy Konferencji rozważali możliwość powtórnego ożenku duchownych, którzy w wyniku zdarzeń losowych zostali wdowcami ${ }^{32}$. W toku dyskusji stwierdzono, że pomimo pasterskiej troski taki działanie byłoby znaczącym naruszeniem norm kanonicznych.

Problem małżeństw mieszanych był i pozostaje nadal wielkim wyzwaniem współczesnego Prawosławia. Dyskusja, która była prowadzona w czasie obrad II Konferencji Ogólnoprawosławnej na ten temat jednoznacznie wskazywała, że należy zezwalać na takie małżeństwa. O ile małżeństwo $\mathrm{z}$ chrześcijaninem nie prawosławnym jest dopuszczalnym, to małżeństwa osoby prawosławnej z nie chrześcijaninem (agnostykiem, wyznawcą innej religii) nie może być pobłogosławione przez Kościół. Należy jednak zauważyć, że dokument zezwalał lokalnym Kościołom na

\footnotetext{
30 Kanon Apostolski 69 brzmi: „Jeśli którykolwiek biskup, prezbiter, diakon (...)nie pości w okresie Wielkiego postu przed Wielkanocą, lub w środę albo piątek z wyjątkiem przeszkody na niemoc cielesną, niech będzie pozbawiony godności. Jeśli będzie to laik, należy go odłączyć od Komunii świętej”.

31 Tekst w j. polskim zob. T. Kałużny, dz. cyt. s. 398-399

32 Synodica VIII, dz. cyt. s. 125
}

samodzielne rozwiązywanie tych problemów. Według autorów dokumentu takie małżeństwa mogą być dopuszczalne: „małżeństwo między prawosławnymi i niechrześcijanami lub niewierzącymi jest absolutnie zabronione według reguł kanonicznych (akrybii). Lokalne Kościoły prawosławne mogą jednak zdecydować w przypadku takiego małżeństwa co do zastosowania ekonomii duszpasterskiej dla strony prawosławnej, biorąc pod uwagę szczególne potrzeby duszpasterskie" (7b).

Zagadnienie dotyczące stopnia pokrewieństwa oparte zostało w znaczącej mierze na kanonie 54 Soboru in Trullo. W projekcie przyjętym w 1982 r. stwierdzono, że „zawieranie związku małżeńskiego do 5-go stopnia jest niedozwolone". Problem jednak wydaje się, nie został rozwiązany do końca i dlatego w dokumencie, który został przyjęty przez Sobór na Krecie nie wskazuje się na konkretne stopnie pokrewieństwa, lecz autorzy tekstu odnoszą się do kanonu 53 i 54 Soboru in Trullo.

Dokument o małżeństwie był uzupełniany i poprawiany przez Specjalną Komisję, która była w tym celu powołana i która spotkała się na swoim trzecim posiedzeniu w dniach 29 marca - 3 kwietnia 2015 r. w Chambésy. Jednak gruntowna zmiana treści dokumentu została przyjęta na Synaksie zwierzchników lokalnych autokefalicznych Kościołów prawosławnych w styczniu 2016 r. Propozycja Patriarchatu Moskiewskiego wskazywała na potrzebę dodania paragrafu, który podkreślałby ważność instytucji małżeństwa w obecnych czasach kiedy, instytucja ta jest zaniedbywana na rzecz związków nieformalnych. $\mathrm{W}$ ten sposób dokument, który w początkowo nazywał się: Przeszkody w zawarciu związku matżeńskiego stał się dokumentem: Sakrament matżeństwa i jego przeszkody. Zmiany, które nastąpiły pomiędzy początkową wersją i końcową dokumentu, jak też dyskusje, które towarzyszyły jego powstawaniu, są bardzo ciekawe i zasługują na głębszą analizę. Z powodu braku miejsca jednak ograniczę się do przedstawienia oficjalnego dokumentu.

Dokument wyraźnie podzielony jest na dwie części, pierwsza odnosi się do postrzegania małżeństwa w Kościele prawosławnym, druga wskazuje na przeszkody w jego zawarciu. Ojcowie soborowi w pierwszej części w tradycyjny sposób ukazują jakie znaczenie ma instytucja małżeństwa w Kościele. Zwracają uwagę, że obecnie małżeństwo znajduje się w obliczu pewnego zagrożenia: „Instytucja rodziny znajduje się obecnie w obliczu zagrożenia sekularyzacją, jak również relatywizmem moralnym. Kościół prawosławny uczy o świętości małżeństwa jako fundamentalnej i nie zaprzeczalnej nauce Kościoła" ( I). Małżeństwo jest instytucją, która została ustanowiona wraz ze stworzeniem pierwszych ludzi, Adama i Ewy. Dlatego też zauważa się w dokumencie: „Zjednoczenie mężczyzny i kobiety w Chrystusie stanowi Mały Kościół lub obraz Kościoła" (I). Wspólnota, która wynika z małżeństwa, znajduje swoje odzwierciedlenie w społeczeństwie: „Ona (wspólnota) potwierdza ochronę i wychowanie dzieci zarówno w misji duchowej Kościoła, jaki funkcjonowaniu społeczeństwa" (I). Autorzy dokumentu wyrażają zaniepokojenie z powodu kryzysu instytucji małżeństwa i zachę- 
cają by „biskupi i duszpasterze rozwijali wzmożoną pracę w sferze duszpasterstwa, aby ojcowsko bronić wierzących wspierając ich, aby umocnili swoją nadzieję, która została zachwiana w wyniku rozmaitych trudności" (I). Nieformalne związki stanowią swego rodzaju niebezpieczeństwo dla instytucji rodziny, przed czym ostrzegają Ojcowie soborowi: „Wywierany we współczesnym świecie nacisk na uznanie nowych form partnerstwa jest realnym zagrożeniem dla prawosławnych chrześcijan" (I). Autorzy dokumentu zwracają uwagę na to, że Kościół nie może zaakceptować związków partnerskich zarówno obojga płci jak też związków jednej płci: „Kościół nie uznaje związków partnerskich jednej lub obydwu płci swoich członków, lub też jakiejkolwiek formy partnerstwa innej niż małżeństwo" (I). Konsekwencje kryzysu społecznego znajdują swój wyraz w „groźnym wzroście liczby rozwodów”, co w znaczący sposób niepokoi Kościół. Podobnie znacząca liczba aborcji jest również konsekwencją tego kryzysu, dlatego też na koniec pierwszej części dokumentu Ojcowie wzywają: „Kościół prawosławny z miłością wzywa swoje dzieci oraz wszystkich ludzi dobrej woli do zachowania wierności wobec świętości rodziny" (I).

W drugiej części dokumentu zostały wyrażone w sześciu punktach czynniki, które stanowią lub mogą stanowić przeszkody w zawarciu związku małżeńskiego. Należałoby dokładnie omówić wszystkie te punkty i historię ich powstawania, w niniejszym opracowaniu jednak skupię się jedynie na krótkiej prezentacji tych zagadnień. Jako pierwszy czynnik stanowiący przeszkodę $\mathrm{w}$ zawarciu związku małżeńskiego Ojcowie soborowi wymieniają: pokrewieństwo, powinowactwo, adopcję i pokrewieństwo duchowe. Brak jest jednak szczegółowych wskazań do którego stopnia z wyżej wymienionych przeszkód związek małżeński jest zabroniony. Autorzy tekstu zsyłają się na kanony 53 i 54 Soboru in Trullo i wskazują, że również powinna być brana pod uwagę $\mathrm{w}$ takich kwestiach „praktyka kościelna (...) obecnie stosowana w lokalnych autokefalicznych Kościołach prawosławnych" (II,1) ${ }^{33}$. W naturalny sposób dokument wskazuje, że małżeństwo, które nie zostało ostatecznie rozwiązane, również stanowi przeszkodę dla ponownego zawarcia (p.2). Nie mogą również wstępować w związek małżeński, osoby, które są w stanie zakonnym, lub będące kapłanami (p.3 i 4). Ważnym punktem natomiast jest podejście do zagadnienia małżeństw mieszanych wyznaniowo. Wydaje się, że ten punkt pozostaje dość niejasnym. $Z$ jednej strony autorzy dokumentu zsyłają się na kanon 72 Soboru in Trullo, wskazujący, że związki mieszane wyznaniowo lub religijnie nie mogą mieć miejsca. Z drugiej natomiast pozostawia się Kościołom lokalnym swobodę rozpatrywania tej

\footnotetext{
33 Wydaje się jednak, że współczesna praktyka kościelna, powołując się na podręczniki Prawa Kanonicznego nie zupełnie zgodna jest z tym co zostało określone w wyżej wymienionych kanonach. Dla przykładu, według kanonu 53 in Trullo, wiązek małżeński może być zawarty poczynając od czwartego stopnia linii bocznej. Natomiast praktyka kościelna wskazuje, że najniższym stopniem pozwalającym na zawarcie małżeństwa jest stopień piąty. Zob. A. Znosko, Prawosławne Prawo Kościelne, Warszawa 1975, s. 75. W tym wypadku wymogi kanoniczne są mniej rygorystyczne niż praktyka kościelna.
}

kwestii „zgodnie z zasadami świętych kanonów, w duchu duszpasterskiej rozważności, w celu zbawienia człowieka" (p.5) $)^{34}$. Ogólnie w dokumencie znajdujemy zachętę do brania pod uwagę przepisy państwowe $\mathrm{w}$ dziedzinie prawa małżeńskiego „o ile nie przekraczają one granic kościelnej ekonomii”.

\section{Autonomia i sposób jej ogłaszania}

Dokument dotyczący Autonomii i sposobu jej ogłaszania podobnie jak tekst o diasporze nie ulegał znaczącym zmianom na przestrzeni okresu jego przygotowań. Dokument ten został opracowany i przyjęty jako jeden $\mathrm{z}$ ostatnich dokumentów przedsoborowych. Jego akceptacja miała miejsce na V Ogólnoprawosławnej Konferencji Przedsoborowej w 2015 r. Natomiast prace przygotowawcze rozpoczęły się po III Konferencji Ogólnoprawosławnej (1986). Dyskusja, która toczyła się w okresie przygotowawczym skupiała się głównie wokół dwóch dróg w dziele nadawania autonomii dla wydzielonej części Kościoła: 1) Pierwszy sposób znacząco podkreślał rolę Patriarchatu Ekumenicznego w tym zakresie, jako Kościoła, który cieszy się największym autorytetem w łonie Kościoła prawosławnego, 2) Drugi wskazywał na zasadniczą rolę Kościoła-Matki na terytorium którego wyodrębnia się autonomiczna struktura i która pozostaje w jurysdykcyjnej zależności od tegoż Kościoła ${ }^{35}$. W dokumencie przyjętym przez Sobór na Krecie (2016) została przyjęta druga opcja, która przydaje najwięcej znaczenia w udzielaniu autonomii dla Kościoła-Matki. Zostało to wyraźnie sformułowane w § 1 omawianego dokumentu: „Instytucja autonomii wyraża w sposób kanoniczny status relatywnej lub częściowej niezależności, konkretnego kościelnego terytorium od Autokefalicznego Kościoła do którego kanonicznie odnosi się. Nadawanie autonomii dla określonego terytorium kościelnego leży w gestii Kościoła-Matki” (p.1). Oznacza to w praktyce, że jeśli określona część Kościoła autokefalicznego pragnie większej niezależności i samodzielności to $\mathrm{z}$ taką prośbą zwraca się do Soboru lub Synodu tegoż Kościoła. Dalszą procedurę opisuje dokument następująco: „Przyjmując taką prośbę, Kościół autokefaliczny na Synodzie ocenia uwarunkowania i przyczyny takiej prośby i przyjmuje postanowienie o nadaniu lub nie nadaniu autonomii. W przypadku pozytywnego rozpatrzenia, zostaje wydany odpowiedni Tomos, który określa terytorialnie granice Kościoła autonomicznego i jego relacje z Kościo-

\footnotetext{
W dużej mierze przyczyna dość niejasnego sformułowania jest stosunek do tego zagadnienia Kościoła gruzińskiego. W styczniu 2016 r. na Synaksie zwierzchników wszystkie lokalne Kościoły przyjęły projekt dokumentu na obrady Soboru. Przedstawiciele Patriarchatu gruzińskiego nie podpisali tego tekstu właśnie $\mathrm{z}$ powodu akceptacji w tekście takich małżeństw. Pomimo nieobecności Kościoła gruzińskiego, Ojcowie Soboru uważali za słuszne wzięcie pod uwagę obiekcji tegoż Kościoła odnośnie do tego tematu.

35 Sprawa nadawania autonomii jak też inne kanoniczne zagadnienia znalazły swój syntetyczny wykład w opracowaniu Metropolity Damaskinosa: Doklad o sovpadienijah ..dz. cyt. Tematy które zostały nakreślone w raporcie to 1) Prawosławna diaspora, 2) Autokefalia i sposób jej ogłaszania, 3) Autonomia i sposób jej ogłaszania, 4) Dyptychy.
} 
łem autokefalicznym do którego się odnosi, odpowiednio z ustanowionymi kryteriami kościelnej Tradycji” (p. 2b). Następnie zwierzchnik Kościoła autokefalicznego powiadamia Patriarchę ekumenicznego i pozostałe Kościoły autokefaliczne o nadaniu autonomii dla danego terytorium (p. 2c). Nowy Kościół autonomiczny w swoich kontaktach ogólnoprawosławnych i międzykonfesyjnych działa zawsze poprzez Kościół autokefaliczny. Nadawanie autonomii może odbywać się jedynie $\mathrm{w}$ granicach terytorium danego Kościoła autokefalicznego, nie może odbywać się na tzw. terytoriach diasporalnych, z wyjątkiem jednak kiedy zaistnieje sytuacja szczególna (p. 2e).

\section{Prawosławna Diaspora}

Zagadnienie diaspory prawosławnej jest jednym z najbardziej aktualnych i żywych problemów, które potrzebują kanonicznej regulacji. Projekt dokumentu dotyczący prawosławnej diaspory został przyjęty na IV Ogólnoprawosławnej Konferencji Przedsoworowej w Chambésy w 2009 r. Prace jednak nad tym dokumentem rozpoczęły się znacznie wcześniej. Zagadnienie diaspory znalazło swoje opracowanie we wcześniej wspomnianym raporcie metropolity Damaskinosa z 1987 r. w sprawie punktów wspólnych i rozbieżności na temat postrzegania czterech tematów, które pozostały do opracowania jako projekty na przyszły Sobór ${ }^{36}$.

W nadesłanych przez poszczególne Kościoły opracowaniach rysowało się wspólne stanowisko co do potrzeby jak najszybszego rozwiązania problemu diaspory. Potrzeba ta wypływa z samej eklezjologii prawosławnej jak też wymogów kanonicznych opartych na 8 kanonie I Soboru Powszechnego, gdzie mowa jest o tym, że w jednym mieście może być tylko jeden biskup. Natomiast główna linia rozbieżności rysowała się na poziomie interpretacji roli Patriarchatu ekumenicznego wobec Kościołów, które funkcjonują poza terytorium autokefalicznych Kościołów prawosławnych. Dyskusje i prace nad przygotowaniem projektu dokumentu prowadzone były przez Komisje przygotowawcze w 1990 i 1993 r. Rezultatem tych spotkań było wypracowanie dokumentu, który został przedłożony IV Ogólnoprawosławnej Konferencji Przedsoborowej w 2009 r. w Chambésy. Konferencja uzupełniła i przyjęła dokument przedkładając jako projekt na obrady przyszłego Soboru.

Należy zaznaczyć, że problem diaspory nie został definitywnie rozwiązany i wyraźnie zostało to zaznaczone w dokumencie przyjętym na Krecie 2016 r.: „,wszystkie święte Kościoły prawosławne posiadają zgodną wolę aby problem diaspory został rozwiązany możliwie jak najszybciej zgodnie z wymogami prawosławnej eklezjologii i tradycji jak też praktyką kanoniczną Kościoła prawosławnego" (p. 1a). Tym samym wskazuje się, że obecne propozycje zawarte w dokumencie nie rozwiązują całkowicie tego zagadnienia: ,na obecnym etapie nie jest możliwym z powodów historycznych i pastoralnych przejście

\footnotetext{
36 Tamże
}

bezpośrednie do właściwego porządku kanonicznego Kościoła odnośnie do tego zagadnienia, tzn. że w jednym miejscu powinien być tylko jeden biskup. Dlatego też Konferencja doszła do wniosku, że należy stworzyć sytuację przejściową, która przygotuje grunt dla rozwiązania czysto kanonicznego tego problemu" (p. 1b). Rozwiązaniem przejściowym jest utworzenie tzw. Zgromadzeń Biskupów na terenach diasporalnych. Zgromadzenie Biskupów ma być złożone z wszystkich kanonicznych biskupów pochodzących z autokefalicznych Kościołów lokalnych, przysłanych aby otaczać duchową opieką emigrantów, którzy znaleźli się w danych krajach. W ocenie przedstawicieli lokalnych Kościołów prawosławnych, zgromadzonych w czasie spotkania Komisji w 1990 i 1993 r. takich Regionów, gdzie powinny powstać Zgromadzenia Biskupów powinno było być $8^{37}$, natomiast IV Konferencja (2009) proponowała 12 takich Regionów ${ }^{38}$, Sobór na Krecie (2016) natomiast ustanowił 13 Regionów (p.3) $3^{39}$. Wszyscy biskupi pozostający w zależności kanonicznej od swoich Kościołów - Matek w tych Regionach powinni utworzyć Zgromadzenie, które ma „na celu ukształtowanie wspólnej pozycji Kościoła prawosławnego w odniesieniu do różnych zagadnień" (p.5). Głównym zadaniem i odpowiedzialnością tych Zgromadzeń „będzie troska o ukazanie jedności Prawosławia i rozwijanie wspólnych działań wszystkich prawosławnych poszczególnego regionu w celu służenia potrzebom pastoralnym mieszkających tam prawosławnych, wspólne reprezentowanie wszystkich prawosławnych wobec innowierców i całego społeczeństwa regionu" (p.2c). Mówiąc innymi słowy współpraca i współdziałanie wszystkich prawosławnych biskupów skupionych w danym Regionie ma świadczyć o jedności Kościoła prawosławnego, ale również zaowocować wspólnymi inicjatywami. Zwoływanie i przewodniczenie Zgromadzeniu Biskupów należy do zadań Przewodniczącego Zgromadzenia.

Niezwykle ważnym uzupełnieniem dokumentu o diasporze jest Regulamin funkcjonowania Zgromadzeń Biskupich w prawostawnej diasporze, który określa kompetencje i uprawnienia tego organu. Zgromadzenie Biskupów posiada swego przewodniczącego i komitet wykonawczy w postaci jednego lub dwóch wiceprzewodniczących, sekretarza i skarbnika. „Przewodniczącym ex officio zostaje pierwszy biskup Patriarchatu Ekumenicznego" (Art. 4). Jeden lub więcej wiceprzewodniczących również ex officio jest wyznaczanych spośród biskupów-członków Zgromadzenia według porządku dyptychów. Funkcję sekretarza i skarbnika może pełnić osoba nie posiadająca godności

Zob. Mežprawoslawnaja Podgotovitielnaja Komisja Sviatago $i$ Wielikogo Sobora 7-13 nojabrja 1993; Chambesy 1994, s. 218 (maszynopis).

38 Zob. Synodica XII, Secretariat pour la preparation du Saint et Grande Concile de l'Eglise Orthodoxe, Chambésy 2015 s. 258

39 Regiony ustalone na Soborze (2016) to: 1) Kanada, 2) Stany Zjednoczone Ameryki, 3) Ameryka Lacińska, 4) Australia, Nowa Zelandia i Oceania, 5) Wielka Brytania i Irlandia, 6) Francja, 7) Belgia, Holandia i Luksemburg, 8) Austria, 9) Włochy i Malta, 10) Szwajcaria i Lichtenstein, 11) Niemcy, 12) Skandynawia (z wyłączeniem Finlandii), 13) Hiszpania i Portugalia. 
biskupiej. W Artykule 5 zostały opisane prawa i kompetencje Zgromadzenia Biskupów. Oprócz już wskazanych wyżej kompetencji, do najważniejszych zadań Zgromadzenia należy „koordynowanie i promowanie leżącej w zakresie wspólnego zainteresowania działalności w sektorach duszpasterstwa, katechetyki, życia liturgicznego, wydawania literatury religijnej, mediów, edukacji kościelnej itp." (Art. $5 b$ ). Działalność biskupów w Zgromadzeniu nie ogranicza w żaden sposób ich działalności pasterskiej w diasporze, która została im powierzona przez Kościoły-Matki, z których oni się wywodzą. Biskupi, którzy przysyłani są z Kościołów aby otaczać duchową opieką swoich wiernych za granicą nie potrzebują akceptacji Zgromadzenia Biskupów. Przyjmowani są do Zgromadzenia z urzędu. Spośród innych istotnych informacji zawartych w Regulaminie dotyczących kompetencji Zgromadzenia należałoby odnotować zadanie badania kanoniczności innych wspólnot prawosławnych, które nie mają odniesienia do kanonicznych Kościołów autokefalicznych. Ponadto Zgromadzenie powinno dbać o przestrzeganie decyzji sądowych podjętych przez biskupów wobec duchownych danej diecezji w diasporze. Duchowny na którego zostały nałożone sankcje przez biskupa jednej jurysdykcji nie może być przyjętym przez biskupa innej jurysdykcji (Art. 6,3). W Regulaminie zaznacza się również, że wszystkie decyzje podejmowane przez Zgromadzenie biskupów powinny zapadać jednogłośnie (Art. 10,1).

\section{C) Dokumenty tematyczne, które odnoszą się do zewnętrznego życia Kościoła}

\section{Relacje Kościoła prawosławnego $\mathrm{z}$ pozostałym światem chrześcijańskim}

Dokument dotyczący Relacji Kościola prawosławnego z pozostalym światem chrześcijańskim, dotyczy stosunku Prawosławia wobec innych wspólnot i Kościołów chrześcijańskich, z którymi Prawosławie w ten czy inny sposób podtrzymuje swoje relacje. Zagadnienie relacji ekumenicznych Kościoła prawosławnego było dyskutowane na III Ogólnoprawosławnej Konferencji Przedsoborowej w 1986 r. Konferencja wówczas przyjęła cztery dokumenty, spośród których dwa dotyczyły ekumenizmu. Były to dokumenty: 1) Prawostawie wobec ruchu ekumenicznego i 2) Relacje Kościoła prawosławnego z calym światem chrześcijańskim ${ }^{40}$. Decyzją Synaksy zwierzchników w marcu 2014 r. postanowiono poddać gruntownej weryfikacji dwa wyżej wymienione teksty przez Komisję Specjalną. Komisja w czasie swego pierwszego spotkania w dniach 29 września - 4 października 2015 r. uważała za słuszne $\mathrm{z}$ tych dwu dokumentów stworzyć jeden. W ten sposób usunięto część tekstu z dokumentu Relacje Kościota prawosławnego z pozostałym światem chrześcijańskim opisującego historię poszczególnych dialogów i włączono tekst z dokumentu Prawoslawie wobec ruchu ekume-

\footnotetext{
40 Tłumaczenie obydwu dokumentów zob. T. Kałużny, dz. cyt. s. 406417
}

nicznego ${ }^{41}$. W ten sposób powstał nowy rozszerzony tekst dotyczący ekumenizmu jako projekt na obrady Świętego i Wielkiego Soboru. Należy zaznaczyć, że tekst ten okazał się chyba najtrudniejszym spośród wszystkich dyskutowanych dokumentów. Poświęcono mu najwięcej czasu w czasie obrad i jak się okazuje znacząca liczba biskupów nie podpisała tego dokumentu ${ }^{42}$.

Tekst, pomimo braku wyraźnego podziału składa się niejako z czterech części: 1) punkty 1-6 stanowią swoisty wstęp gdzie wyrażona została troska Kościoła wobec podziałów jakie zaistniały w chrześcijaństwie; 2) punkty 7-15 wskazują w jaki sposób odbywają się dialogi teologiczne, które prowadzi Kościół prawosławny; 3) w punktach 16-21 opisano w jaki sposób Kościół prawosławny postrzega swoją rolę w Światowej Radzie Kościołów; 4) ostatnie trzy punkty 22-24 stanowią zakończenie, gdzie wyrażona została potrzeba kontynuowania relacji między chrześcijańskich.

$\mathrm{Na}$ początku dokumentu Ojcowie soborowi stwierdzają, że „Kościół prawosławny będąc Jednym, Świętym, Powszechnym i Apostolskim (...) wierzy z przekonaniem, że zajmuje główne miejsce w kwestii promowania chrześcijańskiej jedności we współczesnym świecie” (p.1). To przekonanie i potrzeba jedności, piszą autorzy dokumentu, powtarzane jest na wszystkich nabożeństwach i wyraża się w słowach: „o zjednoczenie wszystkich (...)”. Dialogi bilateralne, które prowadzi Kościół prawosławny jak też udział w ruchu ekumenicznym ugruntowane są na poszukiwaniu wspólnej tradycji i jedności, która istniała w starożytnym Kościele „na podstawie prawdy wiary i tradycji starożytnego Kościoła siedmiu Soborów powszechnych, jedności wszystkich chrześcijan" (p.5) ${ }^{43}$. Dialogi, które prowadził lub obecnie prowadzi Kościół prawosławny zostały określone przez Ogólnoprawosławne Konferencje Przedsoborowe. Przyjęcie decyzji na poziomie panprawosławnym angażuje $\mathrm{w}$ proces cały Kościół. Jednak, jeśli któryś z autokefalicznych Kościołów z tej czy innej przyczyny wycofa się z któregoś z prowadzonych dialogów bilateralnych, nie oznacza to przerwania dialogu. Kościół ten powinien poinformować Patriarchę ekumenicznego o swojej decyzji i wyjaśnić powód wycofania się. Taka nieobecność powinna być przedmiotem dyskusji komisji prawosławnej przed rozpoczęciem sesji dialogu (p.9).

\footnotetext{
Wydaje się, że decyzja Komisji Specjalnej o stworzeniu jednego dokumentu była absolutnie słuszna. Ponadto część tekstu z dokumentu opisująca poszczególne dialogi, które prowadził Kościół prawosławny z innymi Kościołami okazała się zupełnie nie aktualna. Opisanie nowej sytuacji dialogów wkrótce znowu okazało by się nie aktualnym. Dlatego też w nowym projekcie dokumentu opisanie poszczególnych dialogów nie występuje.

${ }^{42}$ Tekst został oczywiście przyjęty przez Sobór z tego względu, że znacząca większość biskupów podpisała dokument, stanowili oni większość we wszystkich lokalnych Kościołach autokefalicznych.

43 Uzasadnienie udziałuKościoła prawosławnego w ruchuekumenicznym, jako odnalezienie wspólnych korzeni z innymi chrześcijanami w nauczaniu Kościoła siedmiu Soborów powszechnych najszerzej było wyrażane przez ks. Georga Fłorowskiego. Wydaje się, że zasada, którą wyrażał rosyjski teolog, znalazła akceptację w świecie prawosławnym. Zob. K. Leśniewski, Ekumenizm w czasie. Prawosławna wizja jedności w ujęciu Georges'a Florovsky'ego, Lublin 1995.
} 
W dokumencie wyraźnie jest określony cel dialogów: „wspólnym celem wszystkich jest ostateczne przywrócenie jedności w prawidłowej wierze i miłości” (p.12). Zakończenie dialogu ogłaszane jest przez Patriarchę ekumenicznego, który wcześniej porozumiał się w tej sprawie z pozostałymi zwierzchnikami lokalnych Kościołów autokefalicznych. Jeśli zdarzyła by się sytuacja, że po zakończeniu któregoś z dialogów byłaby podejmowana decyzja o przywróceniu jedności, powinna ona zostać podjęta jednogłośnie przez wszystkie lokalne autokefaliczne Kościoky (p.15)

W dokumencie wyraźnie jest określone, że jednym z głównych organów współczesnego ruchu ekumenicznego jest Światowa Rada Kościołów (ŚRK), chociaż inne organizacje ekumeniczne, również odgrywają ważną rolę (p. 16). ŚRK stanowi platformę dla współpracy pomiędzy Kościołami, natomiast nie jest i nie może myć uważana za federację Kościołów. Dlatego też, mając na uwadze swoją tożsamość wywodzącą się ze starożytności i nauczania siedmiu Soborów powszechnych, Kościół prawosławny nie akceptuje idei „równości konfesji” (p.18). W dokumencie zwraca się uwagę $\mathrm{i}$ cytowany jest fragment deklaracji z Toronto (1950) „Kościół, Kościoły i Światowa Rada Kościołów”, gdzie określona została rola ŚRK: „Celem Światowej Rady Kościołów nie jest doprowadzenie przez negocjacje do łączenia się Kościołów - co mogą czynić tylko same Kościoły z własnej inicjatywy - lecz wytwarzanie między Kościołami wzajemnych życzliwych kontaktów (...). Żaden Kościół nie jest obowiązany zmieniać swojej eklezjologii w konsekwencji przystąpienia do Rady"44 (p. 19). Ojcowie soborowi zwracają uwagę na pracę komisji „Wiara i Ustrój” działającą w ramach ŚRK i podkreślają jej znaczące osiągniecia w dziedzinie teologii, oraz wskazują, że istnieje potrzeba „wzmocnienia pracy komisji” (p.21). Jednocześnie w tym samym punkcie zauważa się, że „Kościół prawosławny ma wszakże zastrzeżenia do kluczowych zagadnień wiary i ustroju, ponieważ nieprawosławne Kościoły i wyznania odeszły od prawdziwej wiary Jednego, Świętego i Apostolskiego Kościoła".

W końcowych punktach dokumentu została zwrócona uwaga na istniejące $\mathrm{w}$ prawosławnym świecie grupy, które „pod pretekstem zachowania lub rzekomej obrony prawdziwego Prawosławia rozrywają jedność Kościoła” (p.22). Nie przypadkowo takie stwierdzenie znalazło się właśnie w tym dokumencie. Środowiska o poglądach dość radykalnych najczęściej zarzucają hierarchii kościelnej sprzeniewierzenie się Prawosławiu poprzez kontakty ekumeniczne ${ }^{45}$. Ojcowie soborowi zwracają uwagę ponadto, że należy modlić się o to aby nastał taki czas kiedy „,nastanie jedno stado i jeden pasterz" (J 10,16).

\footnotetext{
44 Deklaracja z Toronto III, 2.3; IV,4

45 Takie poglądy wyrażane są zarówno przez niektórych hierarchów kościelnych, najczęściej takich, którzy nie są w jedności z pozostałym Prawosławiem, lub też mają zatargi z własnym Kościołem. Istnieje też ruch osób świeckich, gdzie wręcz nawołuje się do zrywania jedności z „,biskupami ekumenistami”.
}

2. Misja Kościoła prawosławnego we współczesnym świecie. Wkład Kościoła prawosławnego w osiągnięcie pokoju sprawiedliwości, wolności, braterstwa i milości między narodami oraz zniesienie dyskryminacji rasowej i innej.

Dokument ten nazywany jest „dokumentem o pokoju” lub „misji Kościoła”. Tytuł jego na przestrzeni okresu przygotowawczego uległ pewnej modyfikacji. Jego początkowa wersja brzmiała: Wkład lokalnych Kościołów prawostawnych $w$ realizacje chrześcijańskich ideałów pokoju, wolności, braterstwa i mitości miedzy narodami oraz zniesienie dyskryminacji rasowej. Dokument o tak brzmiącym tytule został przyjęty jako projekt na przyszły Sobór przez III Ogólnoprawosławną Konferencję Przedsoborową w 1986 r. Zgodnie z decyzją Synaksy zwierzchników w marcu 2014 r. jego tekst został poddany rewizji przez powołaną Komisję Specjalną. Komisja zajmowała się zmianami omawianego tekstu na swoim drugim spotkaniu, które przebiegało w dniach 15-21 lutego 2015 r. w Chambésy. Dokument został przeredagowany w swojej treści, jak też sam tytuł uległ pewnej modyfikacji ${ }^{46}$. Ostateczna wersja dokumentu została zatwierdzona przez V Ogólnoprawosławną Konferencję Przedsoborową w 2015 r. i otrzymała brzmienie: Misja Kościoła prawosławnego we wspótczesnym świecie. Wkład Kościoła prawostawnego $w$ osiagnięcie pokoju sprawiedliwości, wolności, braterstwa i milości między narodami oraz zniesienie dyskryminacji rasowej i innej ${ }^{47}$. Jest to najdłuższy dokument, który został przyjęty, przez Sobór na Krecie (2016). Składa się z sześciu rozdziałów oznaczonych kolejnymi literami alfabetu, poprzedzonych wstępem. Należy stwierdzić, że jest to tekst głęboko teologiczny, na bazie którego wyrażono szereg poglądów dotyczących współczesnego świata. Już na początku Ojcowie Soboru zauważają, że słowa Chrystusa: „Idąc więc, czyńcie uczniami wszystkie narody, chrzcząc je w imię Ojca i Syna i Świętego Ducha..." (Mt 28,19), pozostają permanentnym wezwaniem dla Kościoła do głoszenia Słowa Bożego. Jednak „Misja ta powinna być wypełniana nie agresywnie lub też za pomocą różnych form prozelityzmu, lecz w miłości, pokorze i z poszanowaniem tożsamości każdego człowieka oraz kulturowej specyfiki każdego narodu" (Wstęp).

Poszczególne rozdziały zawarte w dokumencie dotykają zagadnień: A) godności osoby ludzkiej, B) wolności i odpowiedzialności, C) pokoju i sprawiedliwości, D) pokoju i zapobieganiu wojnie, E) postawy Kościoła wobec dyskryminacji, F) misji Kościoła prawosławnego jako świadectwa miłości w posłudze. Pismo Święte jak też nauczanie Ojców Kościoła dotyczące godności człowieka, stawia go na szczególnym miejscu w planie Bożego

\footnotetext{
46 Można stwierdzić, że właściwy tytuł dokumentu to : Misja Kościoła prawosławnego we współczesnym świecie, druga część tytułu stanowi właściwie podtytuł.

47 Zob. opinię o tym tekście, Z. Kijas, Kościót prawostawny wobec problemów wspótczesnego świata z perspektywy Soboru Wszechprawosławnego, [w:] Przed Soborem Wszechprawosławnym, dz. cyt. s. $185-204$.
} 
stworzenia. Dlatego też, każdy człowiek zasługuje na to by cieszyć się pokojem. Czynienie pokoju w ten sposób wynika ze specjalnego i wyjątkowego powołania człowieka. Dlatego też „Lokalne Kościoły prawosławne mogą przyczynić się do międzyreligijnego porozumienia i współpracy w celu pokojowego współistnienia oraz społecznego współżycia między narodami bez implikowania przez to jakiegokolwiek synkretyzmu" (A,3). Wolność jest darem Bożym dla człowieka. Jest ona dana by człowiek rozwijał się ku duchowej doskonałości. Wolność może też zostać wykorzystana w odwrotnym kierunku. Może ona prowadzić do oddalania się od Boga, co powoduje istnienie zła w postaci przemocy, rozluźnienia obyczajów, uleganiu nałogom, szerzeniu rasizmu, wzrostowi zbrojeń, wybuchom wojen itp. Konsekwencją niewłaściwego wykorzystania wolności może też być „niekontrolowane wykorzystywanie biotechnologii i biomedycyny genetycznej w odniesieniu do początku, trwania i końca życia człowieka" $(\mathrm{B}, 2)$. Dla tego też Ojcowie soborowi zsyłając się na Apostoła Pawła powtarzają że „wszystko wolno, ale nie wszystko przynosi korzyść...” (1 Kor. 10,23). Prawdziwa wolność niesie w sobie dojrzałość i odpowiedzialność, dlatego, że „wolność bez odpowiedzialności i miłości prowadzi ostatecznie do utraty wolności" (B,3).

Pokój i sprawiedliwość są Ewangelicznymi czynnikami, które głosił Chrystus i pozostają one głoszone w Kościele. Ewangelia jak też Ojcowie Kościoła stwierdzają, że czynienie pokoju jest zadaniem człowieka. Dokument soborowy nie tylko w teologicznych sformułowaniach nawołuje do pokoju i przestrzega przed wojną lecz zwraca uwagę na możliwość totalnej zagłady ludzkości: „zwłaszcza w przypadkach wojen z użyciem broni masowej zagłady, konsekwencje mogłyby być przerażające, nie tylko z powodu śmierci nieprzewidywalnej liczny ludzi (...). Pojawią się choroby (...), które w katastrofalny sposób wpłyną na następne pokolenia" $(\mathrm{D}, 1)$. Wszelka dyskryminacja innego człowieka sprzeczna jest z zasadą stworzenia człowieka na obraz i podobieństwo Boże: „Kościół prawosławny, wyznaje, że każdy, niezależnie od koloru skóry, religii, rasy płci, narodowości, języka, został stworzony na obraz i podobieństwo Boże" (E,2). Dlatego też żadna dyskryminacja nie może mieć miejsca w Kościele. Ostatni punkt omawianego dokumentu: Misja Kościoła prawostawnego jako świadectwo milości w postudze, dotyka wielu problemów społecznych współczesnego świata. Wyrażony został stosunek Prawosławia do współczesnej sytuacji ekonomicznej (F, 1-5), działania na rzecz pokoju $(F, 6)$, problemu globalizacji i sekularyzacji, manipulacji człowiekiem jakie może nieść i niejednokrotnie niosą środki masowego przekazu (F, 7-9), kryzysu ekologicznego (F, 10), etyki w dziedzinie badań bioetycznych (F, 1113). Ważnym nauczaniem, które zawarto w dokumencie jest etyczne podejście do rodziny i małżeństwa, które może być zawarte jedynie pomiędzy mężczyzną i kobietą. „Jest to aktualne szczególnie w związku z próbami legalizacji w niektórych krajach oraz teologicznego uzasadnienia w niektórych wspólnotach chrześcijańskich form współżycia sprzecznych z chrześcijańskim nauczaniem i tradycją"
(F, 14). Wszystkie ukazane problemy i stosunek Kościoła do nich został uzasadniony teologicznie. Właściwie można powiedzieć, że kwestie te zostały w pewien sposób zasygnalizowane, co nie przeszkadza by temat był dalej rozwijamy i badany w sposób zarówno teologiczny jak i empiryczny.

Podsumowanie. Dokumenty Soboru i ich wartość na poziomie panprawoslawnym

Dokumenty, które zostały przyjęte na Soborze Kreta 2016 r. stanowią niezwykle ważną wykładnię nauczania współczesnego Kościoła prawosławnego. Nie wnoszą one zmian do doktryny Kościoła, lecz wyrażają i można powiedzieć opisują pewną rzeczywistość, którą Kościół przeżywa. W niektórych przypadkach mamy rzeczywiście do czynienia z pewną nową regulacją kanoniczną (dokumenty o autonomii i diasporze), jednak w przeważającej mierze problematyka poruszona $\mathrm{w}$ dokumentach $\mathrm{w}$ ten czy inny sposób przejawiała się wcześniej w opracowaniach i wypowiedziach prawosławnych hierarchów i teologów. Nie wszystkie tematy, które na początku całego procesu przygotowawczego zostały zaplanowane Sobór zdołał opracować i przyjąć. Ogólnoprawosławne Konferencje Przedsoborowe nie zatwierdziły trzech tematów, które wcześniej planowano poddać pod obrady Soboru. Chodzi o zagadnienia: 1) dyptychów w Kościele prawosławnym, 2) rozpatrywanie nadawania autokefalii i 3) zagadnienia wspólnego kalendarza. Według regulaminu Soboru, tylko te tematy, które zostały przyjęte przez Ogólnoprawosławne Konferencje Przedsoborowe mogły stać się obiektem debaty i ewentualnej akceptacji Ojców Soboru.

W znaczący sposób problem nieobecności czterech lokalnych autokefalicznych Kościołów, kładzie się cieniem na autorytecie Soboru. Dlatego też określanie Soboru jako Ogólnoprawosławny czy Wszechprawosławny w takiej sytuacji nie może mieć miejsca. $\mathrm{Z}$ drugiej jednak strony nie można nie zgodzić się z faktem, że spotkanie na Krecie było największym zebraniem świata Prawosławnego od czasu zwołania i przebiegu VII Soboru Powszechnego w 787 r. Z pewnością Sobór w 2016 r. zgromadził taką liczbę biskupów i przedstawicieli lokalnych autokefalicznych Kościołów jaka od VIII w. nie spotykała się. Ponadto należy również podkreślić, że proces soborowy nie był aktem jednorazowego spotkania przedstawicieli poszczególnych lokalnych Kościołów. Proces soborowy w swojej właściwej aktywnej formie rozpoczął się w latach 70-tych ubiegłego wieku. Trwał kilkadziesiąt lat. Dokumenty i stenogramy spotkań wyraźnie świadczą, że udział w tym procesie brali przedstawiciele wszystkich autokefalicznych Kościołów. Wszystkie Kościoły w większym lub mniejszym stopniu wpływały na kształt i treść przyjętych na Soborze dokumentów. Dokumenty, które były zatwierdzane przez Ogólnoprawosławne Konferencje Przedsoborowe, aby stać się projektem na planowany Sobór musiały być podpisane przez przewodniczących wszystkich delegacji. Wreszcie Synaksa zwierzchników, która miała miejsce w styczniu 2016 r. w Chambésy jeszcze raz przyjęła wraz ze zmiana- 
mi wcześniej przygotowane dokumenty jako projekty na Sobór. Ojcowie Soboru na Krecie nie wnieśli znaczących zmian do projektów dokumentów. Jeśli jednak pojawiły się nieznaczne zmiany, uwzględniały one wcześniej sygnalizowane obiekcje Kościołów, które były nieobecne.

W ten sposób należy stwierdzić, że przyjęte dokumenty stanowią owoc wieloletnich starań całego Prawosławia względem wybranych zagadnień i problemów. Wyrażają one również naukę, która przez wiele lat była formułowana przez te Kościoły. Zabrakło jednak ukoronowania w postaci uczestnictwa w Soborze wszystkich, które tak wiele lat stanowiło obiekt dążenia całego świata prawosławnego. Z pewnością wcześniej lub później zostaną podjęte działania dotyczące trzech tematatów, które nie weszły do soborowych dokumentów. Powróci również zagadnienie formalnej akceptacji dokumentów Soboru przez ogół Prawosławia.

\section{Bibliografia}

\section{Teksty źródłowe:}

Orędzie Świętego i Wielkiego Soboru Kościoła Prawosławnego, thum. pol. CW 4/2016 s. 5- 18.

Przestanie Świętego i Wielkiego Soboru Kościoła Prawosławnego do prawosławnego ludu $i$ wszystkich ludzi dobrej woli, thum. pol. CW 4/2016 s. 23-27.

Ważność postu i jego wypetnienie dzisiaj, thum. pol. CW 4/2016 s. 29-33.

Relacje Kościoła prawosławnego z pozostałym światem chrześcijańskim, thum. pol. CW 4/2016 s. 34- 39.

Autonomia i sposób jej ogłaszania, tłum. pol. CW 4/2016 s. 4142.

Prawostawna diaspora, thum. pol. CW 4/2016 s. 44-49.

Sakrament małżeństwa i jego przeszkody, tłum. pol. CW 4/2016 s. 50-53.

Misja Kościoła prawosławnego we wspótczesnym świecie. Wkład Kościoła prawosławnego $w$ osiagnięcie pokoju sprawiedliwości, wolności, braterstwa i miłości między narodami oraz zniesienie dyskryminacji rasowej i innej, thum. pol. CW 4/2016 s. 54-63.

\section{Materialy archiwalne:}

Synodica VIII, Secretariat pour la preparation du Saint et Grande Concile de l'Eglise Orthodoxe, Chambésy- Genève 1994.

Synodica XII, Secretariat pour la preparation du Saint et Grande Concile de l'Eglise Orthodoxe, Chambésy-Gèneve 2015.

Doklad o sovpadienijah i rashoždienijah po četyrem temam po- viestki dnia IV Vsepravoslavnogo Predsobornogo SovieŜanija, Chambésy, Genève, 1987 (maszynopis).

Mežprawoslawnaja Podgotovitielnaja Komisja Sviatago $i$ Wielikogo Sobora 7-13 nojabrja 1993; Chambesy 1994, (maszynopis).

\section{Opracowania:}

Kuźma Andrzej ks., Udział Polskiego Autokefalicznego Kościoła Prawostawnego $w$ przygotowaniach Soboru Wszechprawosławnego [w:] Przed Soborem Wszechprawosławnym, Kraków 2016, s. 151-168. Red. T. Kałużny i Z. Kijas.

Kuźma Andrzej ks., Spotkanie Sekretariatu Soboru Wszechprawostawnego, WPAKP 6 (319) 2016.

Kuźma Andrzej ks., Historia i aktualny stan przygotowań do zwołania Soboru Wszechprawostawnego, cz. I, WPAKP 11 (312) 2015.

Kałużny Tadeusz ks., Nowy Sobór Ogólnoprawosławny, Kraków 2008.

Kijas Zdzisław ks., Kościót prawosławny wobec problemów wspótczesnego świata z perspektywy Soboru Wszechprawosławnego, [w:] Przed Soborem Wszechprawosławnym. Kraków 2016, s. 151-168. Red. T. Kałużny i Z. Kijas.

Leśniewski Krzysztof, Ekumenizm w czasie. Prawosławna wizja jedności w ujęciu Georges'a Florovsky'ego, Lublin 1995.

Jerzy (Pańkowski) bp, Synaksa zwierzchników Lokalnych Cerkwi Prawosławnych. Chambesy (21-28 stycznia 2016 r.), WPAKP 3 (316) 2016.

Znosko Aleksy ks., Prawosławne Prawo Kościelne, Warszawa 1975. 


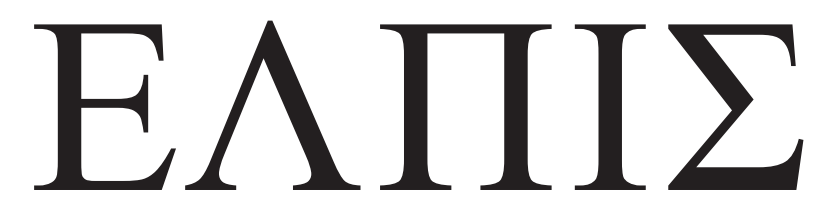

CZASOPISMO TEOLOGICZNE KATEDRY TEOLOGII PRAWOSŁAWNEJ UNIWERSYTETU W BIAŁYMSTOKU

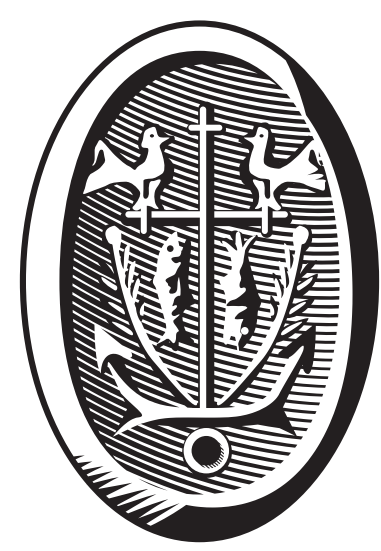

ADRES REDAKCJI

ul. Ludwika Zamenhofa 15, 15-435 Białystok, Polska tel. 85 745-77-80, e-mail: elpis@uwb.edu.pl www.elpis.uwb.edu.pl 